\title{
Highly Efficient Synthesis of Azabicyclo[x.y.0]alkane Amino Acids and Congeners by Means of Rh-Catalyzed Cyclohydrocarbonylation
}

\author{
Wen-Hua Chiou, Nobihiro Mizutani, and Iwao Ojima \\ Department of Chemistry, State University of New York at Stony Brook, Stony Brook, NY \\ 11794-3400
}

\begin{abstract}
A highly efficient method for the synthesis of 1-azabicyclo[x.y.0]alkane amino acid derivatives and their congeners by means of extremely regioselective cyclohydrocarbonylation (CHC) is described. The $\mathrm{CHC}$ reactions are catalyzed by Rh-BIPHEPHOS complex under mild conditions. These $\mathrm{CHC}$ reaction processes involve (i) an extremely linear-selective hydroformylation of the terminal alkene moiety of a dehydrodipeptide substrate, (ii) intramolecular condensation to form cyclic $\mathrm{N}$ acyliminium key intermediate, and (iii) the second cyclization through intramolecular nucleophilic addition of a heteoatom nucleophile to the cyclic $N$-acyliminium moiety to afford the corresponding 1 -azabicyclo[x.y.0] system. This consecutive double cyclization process proceeds with extremely high diastereoselectivity in most cases. This method has been successfully applied to the syntheses of 1-azabicyclo[4.4.0], [5.4.0], and [4.3.0] systems. The mechanisms of the reactions and the rationale for the observed extremely high diastereoselectivity are presented. This Rh-catalyzed CHC process would serve as a highly efficient and versatile method for the syntheses of a variety of conformationally restrained dipeptides, peptidomimetics, alkaloids and other biologically active natural or unnatural products.
\end{abstract}

\section{Keywords}

cyclohydrocarbonylation; rhodium-catalyzed; hydroformylation; cyclization; peptidomimetics; dipeptide-surrogate; dehydrodidpeptide; azabicycloalkane; alkaloid

\section{Introduction}

Azabicyclo[x.y.0]alkane amino acids 1,2 are highly useful synthetic building blocks in the rational design and synthesis of peptidomimetics because these dipeptide surrogates serve as a conformationally fixed scaffold of $\beta$-turn (type II) secondary structures of peptides, ${ }^{3-5}$ which are commonly found in biologically active peptides. These unique heterocyclic frameworks can be used to restrain the backbone geometry and side-chain conformations of the native peptide to investigate the structure-activity relationships. 6,7 As these restrained dipeptide scaffolds possess spatially defined substituents at both $N$ and $C$ terminal positions, azabicyclo [x.y.0]alkane amino acids provide versatile templates for generating combinatorial libraries for

iojima@notes.cc.sunysb.edu.

Supporting Information Available

Characterization data for 1a-k, $(S, S)-\mathbf{2 a},(S, S)$-2d, $,(R, S)-\mathbf{2 e},(S, S)-\mathbf{2 f},(S, S)-\mathbf{6 b},(R, S)-\mathbf{6 b},(S, S)-\mathbf{6 d},(S)-\mathbf{7 h}$, and $(R)-\mathbf{7 h}$, full assignments of NMR spectra and stereochemistry determination for $\mathbf{5 a - k}$, single crystal X-ray analysis data for $(3 S, 6 S, 9 R)-\mathbf{5 h},(3 R, 6 R, 9 S)-\mathbf{5 h}$, and $(3 S, 6 S, 9 S)-\mathbf{5 j}$ are available free of charge via the Internet at http://pubs.acs.org. 
drug discovery. ${ }^{8,9}$ Furthermore, it has been shown that these $\beta$-turn mimics are very useful for the development of efficient enzyme inhibitors and receptor agonists or receptor antagonists. For example, 1-azabicyclo[5.4.0] and [5.3.0]alkane amino acid derivatives have been successfully developed as potent inhibitors of angiotensin-converting enzyme, neutral endopeptidase, atrial natriuretic peptide and enkephalinase. ${ }^{10-13}$

In order to obtain a variety of azabicyclo[x.y.0]alkane amino acids for drug design, discovery, and development, it is essential to secure efficient methods for the syntheses of these compounds. Accordingly, various approaches have been investigated. These synthetic routes to 1-azabicyclo[x.y.0]alkane amino acids bearing a heteroatom in addition to the bridgehead nitrogen can be categorized as follows: (1) Cyclic amine formation through an imine intermediate followed by lactam formation, ${ }^{14-20}$ (2) Cyclic acyliminium formation followed by second cyclization, 11,21,22,23 and (3) Electrochemical cyclization by anodic oxidation of the prolinyl dipeptides (Scheme 1). ${ }^{24-26}$ An aldehyde or acetal group at the terminus of the side chain of an amino acid or amino acid residue is necessary in Routes (1) and (2) for construction of the bridging carbon-nitrogen bond. Route (1) only affords the azabicycles in which the heteroatom is located at the $C$-terminus. Route (2) is a versatile way to azabicyclic compounds. The eteroatom can be either at the $N$-terminus or at the $C$-terminus. The critical issue for this route is the introduction of the aldehyde group. Route (3) is confined to the azabicyclo[x.3.0] system. Consequently, the Route (2) appears to be the most flexible and versatile synthetic strategy.

For the Route (2) synthesis, the preparation of dipeptide derivatives bearing an aldehyde group in one of the amino acid residue and a free hetero-atom nucleophile in the other amino acid residue is essential, but challenging. However, if we can use a masked aldehyde and generate the reactive aldehyde functionality in situ, it would solve this challenging problem associated with the Route (2). To this end, a terminal olefin would serve as the masked aldehyde since it can be converted to the terminal aldehyde through linear selective Rh-catalyzed hydroformylation under neutral conditions. In fact, we reported that the Rh-catalyzed cyclohydrocarbonylation $(\mathrm{CHC})^{23,27-32}$ of $N$-acylallylglycinate proceeded via extremely regioselective hydroformylation, followed by cyclization to form the corresponding hemiamidal. ${ }^{28}$ This hemiamidal readily generated $N$-acyliminium ion that accepted the addition of an alcohol (in alcohol solvent) or isomerized to $N$-acylenamine (in aprotic solvent). 28 Accordingly, if a nucleophile is located within the substrate, the second cyclization should occur via $N$-acyliminium intermediate. ${ }^{33}$ We explored this idea and indeed succeeded in the rapid construction of 1-azabicyclo[4.4.0]decane amino acids with perfect stereochemical control at the bridgehead position through extremely regioselective $\mathrm{Rh}$-catalyzed $\mathrm{CHC}$ process and communicated the first examples of the catalytic cyclization approach to this class of compounds. ${ }^{23} \mathrm{We}$ will describe here a full account of our work on the scope of this highly efficient catalytic bicyclization process as well as the stereochemical issues of the process.

\section{Results and Discussion}

1-Azabicyclo[x.y.0] systems can be constructed in one-step through Rh-catalyzed cyclohydrocarbonylation (CHC) that induces a cascade double cyclization process as shown in Scheme 2. Extremely regioselective hydroformylation of dehydrodipeptide derivative 1 catalyzed by a Rh-BIPHEPHOS ${ }^{34}$ complex gives linear aldehyde 2 exclusively, which is followed by the first cyclization to yield the corresponding hemiamidal $\mathbf{3}$. After the conversion of hemiamidal $\mathbf{3}$ to $\mathrm{N}$-acyliminium ion $\mathbf{4}$, the second cyclization through addition of an intramolecular nucleophile to $\mathbf{4}$ takes place to furnish azabicyclic product 5 .

The substrates of this process, dipeptide derivatives $(\mathbf{1 a - 1} \mathbf{j})$, were readily synthesized from the corresponding enantiopure $N$-protected amino acids (i.e., serine, cysteine, homoserine, $\beta$ - 
aminoalanine, ${ }^{35}$ homocysteine, threonine, and allo-threonine) and enantiopure amino acids or amines (methyl allylglycinate, allylglycinol benzyl ether, methyl vinylglycine, vinylglycinol benzyl ether, ${ }^{36}$ and 3 -aminobutene) under the standard peptide coupling conditions, i.e., EDC, $\mathrm{HOBt}$, and $\mathrm{Et}_{3} \mathrm{~N}$ (only when hydrochloride was used) in $\mathrm{CH}_{2} \mathrm{Cl}_{2}$.

The $\mathrm{CHC}$ reactions of $\mathbf{1 a} \mathbf{- 1} \mathbf{j}$ were carried out using the $\mathrm{Rh}(\mathrm{acac})(\mathrm{CO})_{2}$-BIPHEPHOS catalyst under mild conditions $\left(\mathrm{H}_{2}: \mathrm{CO}=1: 1,4 \mathrm{~atm}, 60^{\circ} \mathrm{C}\right)$. To find the optimal reaction conditions, solvents and additives were examined in the reactions of Boc- $(S)$-Ser- $(S)$-(allyl)Gly-OMe $[(S, S)$-1a] (Scheme 3). The reaction of $(S, S)$-1a proceeded in toluene smoothly to afford the bicyclic dipeptide $(3 S, 6 S, 10 S)-5 \mathbf{a}$ as the single product in $96 \%$ yield. When the reaction was run in THF the cyclization did not occur, but gave aldehyde $(S, S)$-2a in $94 \%$ yield, which confirms that the first step in this process is indeed the extremely linear-selective hydroformylation of the olefin moiety of $(S, S)$-1a. The cyclization also did not take place in the presence of a small amount of 4-(dimethylamino)pyridine (DMAP) even when toluene was used as the solvent. On the contrary, addition of a catalytic amount of $p$-toluenesulfonic acid (PTSA) accelerated the cyclization to give (3S,6S,10S)-5a in 96\% yield. Consequently, the use of toluene as the solvent and a catalytic amount of PTSA as additive was considered to be optimal based on these results. Thus, the standard reaction conditions for the cyclohydrocarbonylation of $\mathbf{1 a}-\mathbf{1} \mathbf{j}$ were set to be the use of $\mathrm{Rh}(\mathrm{acac})(\mathrm{CO})_{2}$-BIPHEPHOS catalyst at $60{ }^{\circ} \mathrm{C}$ and $4 \mathrm{~atm}$ of $\mathrm{H}_{2}$ and $\mathrm{CO}$ in toluene and a catalytic amount (10\%) of PTSA.

The reaction of $(S, R)$-1a in toluene in the presence of PTSA gave $(3 S, 6 R, 10 R)-5 \mathbf{a}$ as single product in $90 \%$ yield (Scheme 3 ). Stereochemistry of the newly formed bridgehead position C-6 of $(S, S, S)-\mathbf{5 a}$ as well as $(S, R, R)-\mathbf{5 a}$ was determined by ROESY analyses. The results indicate that the chiral center in the $\mathrm{C}$-terminus, i.e., the $\mathrm{C}$ - 10 position, is the stereogenic center for the second cyclization that determines the stereochemistry at the bridgehead carbon (C-6).

In the same manner, the reaction of Boc- $(S)$-Ser- $(S)$ - $O$-benzyl(allyl)glycinol $(S, S)$-1 b, bearing a $\mathrm{CH}_{2} \mathrm{OBn}$ group in place of a $\mathrm{CO}_{2} \mathrm{Me}$ group at $\mathrm{C}-10$, was carried out to give azabicyclic product $(S, R, S)$-5b in $82 \%$ yield, while the reaction of the other diastereomer $(R, S)$-1b gave $(3 R, 6 R, 10 S)-\mathbf{5 b}$ in $80 \%$ yield (Scheme 4$)$. Stereochemistry of the products was unambiguously assigned on the basis of NOESY analysis. In both cases, the formation of a small amount of non-cyclized acylenamine, $(S, S)$-6 $\mathbf{b}$ or $(R, S)$-6b was observed. These side products are formed by deprotonation-isomerization of the acyliminium intermediate $\mathbf{4}$ (see Scheme 2) prior to the second cyclization via a nucleophilic addition of the hydroxyl moiety to 4 .

These results confirm that the $\mathrm{C}-10$ position in the $\mathrm{C}$-terminus is the stereogenic center. However, the results also have revealed that the stereochemistry induced at the bridgehead (C-6) position in $\mathbf{1 b}$ is opposite to that in $\mathbf{1 a}$, which indicates that the nature of the substituent at the $\mathrm{C}-10$ position exerts a critical effect on the direction of the second cyclization, generating the bridgehead carbon in the azabicyclic product 5 .

This process is readily applicable for the construction of 1-azabicyclo[5.4.0] system. Thus, the reaction of Boc- $(S)$-homo-Ser- $(S)$-(allyl)Gly-OMe $[(S, S)$-1c] under the standard conditions afforded $(3 S, 7 S, 11 S)-\mathbf{5} \mathbf{c}$ in $87 \%$ yield.

Next, we examined a carbamate group as internal nucleophile to trap the $\mathrm{N}$-acyliminium intermediate 4 . Thus, the reaction of unsaturated dipeptide $(S, S)$-1d, bearing a $\beta$ aminoalanine ${ }^{35}$ moiety, proceeded efficiently under the standard conditions to give (3S, $6 \mathrm{~S}$, $10 S)$-5d as the single product in $95 \%$ yield (Scheme 6). The $(3 S, 6 S, 10 S)$ stereochemistry of $\mathbf{5 d}$ was determined by X-ray crystallographic analysis (see Figure S1, Supporting Information), which is consistent with the case of $(3 S, 6 S, 10 S)-\mathbf{5 a}$ from $(S, S)$-1a (Scheme 2). It should be noted that no 1-azabicyclo[4.3.0] product was formed in spite of the fact that either Boc-amino 
group in the $\beta$-aminoalanine residue could have reacted with the acyliminium intermediate 4d $(\mathrm{R}=\mathrm{Boc}, \mathrm{X}=\mathrm{BocN})$.

In the case of unsaturated dipeptide substrates bearing a cysteine moiety, an $S$-trityl derivative was used to avoid undesirable S-S bond formation as well as possible deactivation of an active catalyst species during the reaction (Scheme 4). Since the thiol group is protected, a spontaneous cyclization cannot take place, which is likely to lead the reaction to undesirable $\mathrm{N}$-acylenamine formation (see 6 in Schemes 4 and 6). In order to circumvent this problem, we designed to carry out the reaction in $\mathrm{MeOH}$ to trap the resulting aldehyde moiety by converting it in situ to the corresponding acetal. Moreover, the Boc protection is not stable under the acidic conditions required to remove the trityl (Tr) group. Thus, the $N$-Boc group should be replaced with a carbobenzoxy (Cbz) group. Consequently, we prepared $N$-Cbz-S-Tr dipeptides $(R, S)$-1e and $(S, S)$-1f as substrates for the two-step bicyclization process.

The reaction of $S$-Tr- $N$-Cbz- $(R)$-Cys- $(S)$-(allyl)Gly-OMe $[(R, S)-1 \mathrm{e}]$ was carried out in $\mathrm{MeOH}$ under the standard conditions, which was supposed to give the dimethylacetal of $2 \mathbf{e}$. However, to our surprise, the reaction gave $\mathbf{2 e}$ in $86 \%$ yield (Scheme 7). The subsequent deprotectioncyclization with a catalytic amount of trifluoroacetic acid (TFA) afforded azabicyclic product $(3 R, 6 S, 10 S)$-5e in $89 \%$ isolated yield (Scheme 7$)$. The $(3 R, 6 S, 10 S)$ stereochemistry of 5e was determined by NOESY analysis, which is consistent with the case of $(3 S, 6 S, 10 S)$-5a from $(S, S)$-1a (Scheme 2).

1-Aza-6-thiabicyclo[5.4.0] undecane amino acid derivative $(3 S, 7 S, 11 S)$-5f was also synthesized from $N$-Cbz- $S$-Tr- $(S)$-homo-Cys-(S)-(allyl)Gly-OMe $[(S, S)$-1f $]$ in the same manner in $84 \%$ yield for two steps (Scheme 8). It may be worthy of note that this azabicyclo [5.4.0] framework is the core part of Omapatrilat, ${ }^{11}$ an efficacious ACE inhibitor developed by the Bristol-Myers Squibb company. The stereochemistry of ( $3 S, 7 S, 11 S)$-5f was determined by NOESY and nOe difference analyses.

We also examined the effect of another chiral center at the side chain of an amino acid residue of unsaturated dipeptide substrates on the stereochemistry of the second cyclization by introducing threonine isomers at the N-terminus. The reaction of Boc- $(L)-\mathrm{Thr}-(S)$-(allyl)GlyOMe $(S, R, S)$-1g under the standard conditions afforded a single azabicyclic product $(3 S, 4 R$, $6 S, 10 S$ )-5g in $85 \%$ yield (Scheme 9). This result alone appears to imply that the additional chiral center does not have any influence on the second cyclization and the stereogenic center is still the one at the $\mathrm{C}-10$ position in the same manner as that observed for $\mathbf{1 a}$ (Scheme 2). However, the reaction of Boc- $(D)$-allo-Thr-(S)-(allyl)Gly-OMe $(R, R, S)$-1g gave $(3 R, 4 R, 6 R$, $10 S)-5$ g as exclusive product in $94 \%$ yield (Scheme 9 ). This result clearly indicates that the chiral centers at the side chain of the $D$-allo-threonine residue serves as the stereogenic centers in the second cyclization. The result makes sense since the chiral centers at the threonine side chain are very close to the reacting hydroxyl group in the second cyclization. This also means that the three chiral centers at the allylglycine residue and the $(L)$-threonine side chain happen to be both inducing $S$ configuration at the bridgehead carbon in the reaction of $(S, R, S)$-1g. The predominant effect of the stereogenic centers at the threonine side chain is also observed in the reactions of Boc-( $L$ )-allo-Thr-(S)-(allyl)Gly-OMe $(S, S, S)$-1g and Boc-(D)-Thr-(S)-(allyl)GlyOMe $(R, S, S)-\mathbf{1 g}$. The reaction of $(S, S, S)-\mathbf{1 g}$ gave a mixture of two azabicyclic products, (3S, $4 S, 6 S, 10 S)$-5g (major, 69\% yield) and (3S,4S,6R,10S)-5g (minor, $17 \%$ yield), while the reaction of $(R, S, S)-\mathbf{1 g}$, afforded two diastereomeric products, $(3 R, 4 S, 6 R, 10 S)-\mathbf{5 g}$ (major, $78 \%$ yield) and (3R,4S,6S,10S)-5g (minor, $10 \%$ yield) (Scheme 9$)$.

In these cases, the three stereogenic centers at the threonie side chain and the allylglycine residue have a conflicting effect on the direction of the second cyclization, but the stereogenic centers at the threonine side chain exert a predominant role. These results also indicate that the 
Boc-NH group at the $\mathrm{C}-3$ position has critical effect on the direction of the second cyclization (vide infra).

The $\mathrm{CHC}$ of unsaturated dipeptides, bearing a vinlyglycine residue in place of an allylglycine residue was challenging due the inherent instability of the vinylglycine residue, which is prone to isomerize to the corresponding conjugated ethyleneglycine residue. In fact, the reaction of Boc- $(S)$-Ser- $(S)$-(vinyl)Gly-OMe $[(S, S)$-1/h $]$ under the standard conditions afforded a mixture of azabicyclic products, $(3 S, 6 S, 9 S)-\mathbf{5 h}$ (major, $48 \%$ yield) and (3S, 6S,9R)-5h (minor, $21 \%$ yield), accompanied by non-cyclized dipeptide $(S)-7 \mathbf{h}$, in $21 \%$ yield (Scheme 10 ). The reaction of $(R, S)$-1h also gave a mixture of $(3 R, 6 R, 9 S)$-5h (major, $42 \%$ yield) and $(3 R, 6 R, 9 R)-\mathbf{5 h}$ (minor, $16 \%$ yield), accompanied by $(R)-7 \mathbf{h}$ in $23 \%$ yield (Scheme 10 ). Then, it was found, unexpectedly, these four distereomeric azabicyclic products $\mathbf{5 h}$ were comprised of two pairs of enantiomers on the basis of the facts that a pair of $\mathbf{5 h}$ showed the identical NMR spectra and the same $[\alpha]_{D}$ value but with opposite signs. The structures of one pair of enantiomers, $(3 S, 6 S$, $9 R)-\mathbf{5 h}$ and $(3 R, 6 R, 9 S)-\mathbf{5 h}$, were confirmed by X-ray crystalselography (see Figure S2 and Figure $\mathbf{S} 3$, Supporting Information). Thus, the other pair of enantiomers, $(3 S, 6 S, 9 S)-5 \mathbf{h}$ and $(3 R, 6 R, 9 R)-\mathbf{5 h}$, were also unambiguously assigned.

The results clearly show that partial epimerization took place at the C-9 position of the product during the reaction. Since it is highly unlikely that the epimerization occurs after the formation of the azabicyclic skeleton $\mathbf{5 h}$, the epimerization should have happened during the hydroformylation step or at the $\mathrm{N}$-acyliminium intermediate stage. For the formation of noncyclized dipeptides $\mathbf{7 h}$, there are two possible pathways, i.e., (a) via hydroformylation of the vinylglycinate residue as a result of low regioselectivity and (b) via hydroformylation of the ethylideneglycinate residue generated in situ by double bond migration. Judging from the fact that no branched aldehyde formation was observed when the electron-withdrawing ester group was replaced with a benzyloxymethyl or a methyl group (substrate $\mathbf{1 i}$ or $\mathbf{1 j}$, vide infra), the possible pathway (b) is most likely to be the case.

As described above, the use of a vinylglycine residue in unsaturated dipeptide substrates causes complications. Accordingly, we replaced the vinylglycine residue with $O$-protected vinylglycinol residue to circumvent the problem. In fact, the reaction of Boc- $(S)-\operatorname{Ser}-(R)-(O-$ benzyl)Glycinol $[(S, R)-\mathbf{1 i}]$ under the standard conditions afforded the corresponding azabicyclo[4.3.0] product $(3 S, 6 S, 9 R)$-5i exclusively in $87 \%$ isolated yield (Scheme 11). However, reaction of the other diasteromer substrate $(R, R)-\mathbf{1 i}$ gave a nearly $1: 1$ mixture of $(3 R, 6 R, 9 R)-5 \mathbf{i}$ and $(3 R, 6 S, 9 R)-5 \mathbf{i}$ in $83 \%$ combined yield although no formation of other side products was observed (Scheme 11). The results indicate that the chiral centers at $\mathrm{N}$-terminus as well as $\mathrm{C}$-terminus are stereogenic centers in these reactions, and $(S, R)$-1i is a matching pair while $(R, R)-\mathbf{1 i}$ is a mismatching pair. As already observed in the reactions of $\mathbf{1 b}$ (Scheme 4), the directing effect of the $\mathrm{PhCH}_{2} \mathrm{OCH}_{2}$ group in $\mathbf{1}$ i on the second cyclization to generate the bridgehead carbon (C-6) is opposite to that of the $\mathrm{CO}_{2} \mathrm{Me}$ group in $\mathbf{1 a}$ (Scheme 3).

In the same manner, the reactions of $N-(S)$-3-buten-1-ylamides of $(S)$ - and $(R)-N$-Boc-serine $[(S, S)-\mathbf{1} \mathbf{j}$ and $(R, S)-\mathbf{1} \mathbf{j}]$ were carried out under the standard conditions. The results were very similar to those for $\mathbf{1 i}$ described above, i.e., the reaction of $(S, S)-\mathbf{1} \mathbf{j}$ afforded $(3 S, 6 S, 9 S)-\mathbf{5} \mathbf{j}$ exclusively in $94 \%$ yield, while that of $(R, S)$-1 $\mathbf{j}$ gave a mixture of $(3 R, 6 R, 9 S)-\mathbf{5 j}$ ( $45 \%$ yield) and $(3 R, 6 S, 9 S)-\mathbf{5 j}$ (34\% yield) (Scheme 12). The structure of (3S,6S,9S)-5j was confirmed by $\mathrm{X}$-ray crystallographic analysis (see Figure S4, Supporting Information). The directing effect of the methyl group in $\mathbf{1} \mathbf{j}$ is the same as that of the $\mathrm{PhCH}_{2} \mathrm{OCH}_{2}$ group in $\mathbf{1 i}$ (although the $S$, $R$ designation is different, the stereochemical sense of the substituents is the same). In this case, however, it appears that the stereogenic center of the $N$-Boc-serine residue has stronger directing effect than the $N$-but-1-en-3-yl moiety. 
In order to confirm the directing effect of the $N$-Boc-serine residue on the second cyclization, we carried out the reaction of the $N$-allylamide of Boc- $(S)$-serine $(S)$-1k under the standard conditions, which gave (3S,6S)-5k (major, 70\% yield) and (3S,6R)-5k (minor, 6\% yield) (Scheme 13). The result confirms the anticipated and substantial directing effect of the stereogenic center in the Boc-serine residue.

\section{Mechanisms of the second cyclization}

As described above, extremely high diastereoselectivity was observed in most of the syntheses of 1-azabicyclo[x.y.0]alkane amino acids and their derivatives by means of the RhBIPHEPHOS-catalyzed cyclohydrocarbonylation (CHC). One might guess that the second cyclization step is thermodynamic control, yielding the thermodynamically most stable products. However, this possibility is easily eliminated by molecular mechanics calculation of the energies of a pair of diastereomers in each case (see Supporting Information). Thus, the extremely diastereoselective second cyclization step should be a kinetically controlled process.

Deslongchamps has reported that a nucleophilic addition to a conformationally rigid didehydropiperidinium ion is controlled by stereoelectronic effects, wherein an axial attack is favored to avoid the unfavorable boat transition state. ${ }^{37}$ Accordingly, the conformation of $\mathrm{N}$ acyldidehydropiperidinium ion $\mathbf{4}$ should play a key role in the second cyclization. To determine the favorable conformation of intermediate $\mathbf{4}$, two conflicting strains, i.e., 1,3-diaxial strain and 1,3-allylic strain, ${ }^{38}$ should play critical roles, i.e., the relative significance of these two strains would determine the conformation. In other words, the predominance of allylic strain (i.e., allylic strain > 1,3-diaxial strain) would render the substituent at C-6 to the axial position, favoring the Conformer A (Scheme 14). whereas the C-6 substituent would take the equatorial position when the 1,3-diaxial strain overwhelms the 1,3-allylic strain, favoring the Conformer B (Scheme 14).

The estimated equatorial preference is $1.2 \mathrm{Kcal} / \mathrm{mol}$ for $\mathrm{CO}_{2} \mathrm{Me}$ and $1.8 \mathrm{Kcal} / \mathrm{mol}$ for methyl group. ${ }^{39-41}$ This indicates the $s p^{3}$-hybridized methyl group at the axial position of C-6 would suffer more from the 1,3-diaxial strain than the $s p^{2}$-hybridized $\mathrm{CO}_{2} \mathrm{Me}$. Accordingly, the $s p^{3}$ hybridized $\mathrm{CH}_{2} \mathrm{OBn}$ group should occupy the equatorial position of $\mathrm{C}-6$ to avoid critical 1,3diaxial strain, while the $s p^{2}$-hybridized $\mathrm{CO}_{2} \mathrm{Me}$ group should take the axial position of C-6 because of the predominant 1,3-allylic strain. Therefore, it is anticipated that the intramolecular nucleophilic addition of the hydroxyl group to the iminium bond of $(S, S)-\mathbf{4 a}$ (Conformer A) takes place from the $s i$ face (i.e., the top face), leading to the formation of $(3 S, 6 S, 10 S)-5 \mathbf{a}$ (Scheme 14). In the same manner, the addition to $(S, R)-\mathbf{4 a}$ (Conformer A) should occur from the $r$ face (i.e., the bottom face) to give ( $3 S, 6 R, 10 R)-5 \mathbf{a}$ (Scheme 14). The experimental results (Scheme 3) are consistent with these anticipations.

As mentioned above, the $\mathrm{CH}_{2} \mathrm{OBn}$ group at C-6 of the intermediate $(S, S)-\mathbf{4 b}$ and $(R, S)-\mathbf{4 b}$ should occupy the equatorial position (Conformer B). Thus, it is anticipated that the intramolecular addition of the hydroxyl group to the iminium bond of $(S, S)-\mathbf{4 b}$ takes place from the $r$ face (bottom face) to afford $(3 S, 6 R, 10 S)-\mathbf{5 b}$, while that of $(R, S)-\mathbf{4 b}$ proceeds through the si face (top face) to give $(3 R, 6 R, 10 S)-\mathbf{5 b}$ (Scheme 15). The experimental results are consistent with the anticipated outcomes (Scheme 4). The proposed mechanism (Scheme 15) is certainly applicable to other nucleophiles, i.e., nitrogen (4d) and sulfur (4e), as well as homologs (4c and 4f). Thus, the reactions of (S,S)-1c (Scheme 5), (S,S)-1d (Scheme 6), $(R, S)$-1e (Scheme 7) and $(S, S)-\mathbf{1 f}$ (Scheme 8$)$ indeed gave the corresponding $\mathbf{5 c - f}$, respectively, in accordance with the proposed mechanism.

For the reactions of Boc- $(D / L)$-Thr-(S)-(allyl)Gly-OMe and Boc- $(D / L)$-allo-Thr-(S)-(allyl) Gly-OMe diastereomers (1g), the chiral center in the threonine or allo-threonine residue serves as additional stereogenic center in addition to the stereogenic center in the $\mathrm{C}$-terminus residue 
(Scheme 9). As described above, the reactions of $(S, R, S)-\mathbf{1 g}$ and $(R, R, \mathrm{~S})-\mathbf{1 g}$ led to the exclusive formation of the corresponding $(3 S, 4 R, 6 S, 10 S)-\mathbf{5 g}(85 \%$ yield) and $(3 R, 4 R, 6 R, 10 S)-\mathbf{1 g}(94 \%$ yield), respectively. In the case of the $(S, R, S)-\mathbf{1 g}$ to $(3 S, 4 R, 6 S, 10 S)-\mathbf{5 g}$ conversion, it appears that the $R$ configuration at the chiral centers in the $L$-threonine and $D$-allo-threonine forms a matching pair with the $S$ configuration at the C-terminus residue that fixes $\mathbf{4 g}$ as Conformer A (Scheme 14). Inspection of the approach of the hydroxyl group to the iminium carbon of $\mathbf{4 g}$ (si-face attack) has revealed that the methyl group at the side chain is exo to the second cycle being formed ("exo-Methyl" approach, Figure 1). Thus, the induction of $6 S$ configuration at the bridgehead is directed by the $S$ configuration at the $\mathrm{C}$-terminus residue in the same manner as that for $(S, S)-\mathbf{4 a}$ (Scheme 14).

However, when $D$-allo-threonine, $L$-allo-threonine and $D$-threonine are used as $\mathrm{N}$-terminus residues, the situation becomes more complicated. In the case of the $(R, R, S)-\mathbf{1 g}$ to $(3 R, 4 R, 6 R$, $10 S)-\mathbf{5 g}$ conversion, $6 R$ configuration was introduced at the bridgehead position exclusively ( $94 \%$ isolated yield)! This means that the chiral center at the C2 position of $D$-allo-threonine residue emerges as the stereogenic center, which directs exclusive re-face attack (pro-6R approach) on the iminium carbon of $(R, R, S)$-4g. The inspection of the possible transition state structures has disclosed an additional critical factor that determines the conformation of the threonine and allo-threonine residues. This critical factor is the intramolecular hydrogenbonding of the hydroxyl group to the BocNH group in non-polar aprotic solvent (toluene). Because of this hydrogen-bonding, the si-attack becomes impossible due to the severe steric conflict between the "endo-Methyl" group of the $D$-allo-threonine residue and the iminium moiety of $(R, R, S)-\mathbf{4 g}$. The steric conflict can be avoided when the hydroxyl group undergoes $r e$-face attack through "exo-Methyl" approach although it should cause 1,3-allylic strain (Figure 1). A very similar analysis is applicable to the $(R, S, S)-\mathbf{4 g}$ case, which favors the reattack (pro-6R approach) of the hydroxyl group of the $D$-threonine residue to give $(3 R, 4 S, 6 R$, $10 S)$-5g as the predominant product (78\% isolated yield). In the case of $(S, S, \mathbf{S})-\mathbf{4 g}$ bearing a $L$-allo-threonine residue, the $s i$-attack is favored, although minor steric conflict exists between the "endo-Methyl" and the iminium moiety, to give $(3 S, 4 S, 6 S, 10 S)-5 \mathrm{~g}$ as the major product (69\% isolated yield). When the same analysis is applied to the most straightforward case, i.e., an apparent "matching pair case $(S, R, S)-\mathbf{4 g}$, the intramolecular hydrogen-bonding indeed fixes the "exo-Methyl" conformation and favors the si-attack (pro-6S approach) of the hydroxyl group of $L$-threonine residue to give $(3 S, 4 R, 6 S, 10 S)$-5g exclusively (Figure 1).

As described above, the reactions of Boc-(S/R)-Ser-(S)-(vinyl)Gly-OMe (1h) gave a mixture of two diastereomeric 1-aza-5-oxabicyclo[4.3.0]nonane products (5h) and non-cyclized dipeptide (7h) (Scheme 10). It is indicated that epimerization of the vinylglycine residue as well as isomerization of the double bond to ethyleneglycine residue took place during the hydroformylation step. The occurrence of the epimerization and the double bond isomerization can be accommodated by assuming the intermediacy of $\pi$-allyl-[Rh]H complex $\mathbf{8 h}$ in competition with hydroformylation, as illustrated in Scheme 16 (only $(S, S)$-1h case is shown: the mechanism is essentially identical for $(R, S)-\mathbf{1 h})$.

A key olefin-Rh complex intermediate, $(S, S)$-1h- $\mathrm{Rh}$, in the Rh-catalyzed hydroformylation reacts with $\mathrm{CO}$ and $\mathrm{H}_{2}$ to give $(3 S, 6 S, 9 S)$-5h as single diastereomer. As a competitive process with the hydroformylation, $(S, S)$-1/h-Rh forms $\pi$-allyl-[Rh]H complex $(S)$-8h, which is in equilibrium with olefin-Rh complex intermediates, $(S, S)$-1h- $\mathrm{Rh},(S, R)-\mathbf{1 h}-\mathrm{Rh}$ and $(S)$-iso-1h$\mathrm{Rh}$. Each olefin-Rh complex reacts with $\mathrm{CO}$ and $\mathrm{H}_{2}$ to give the corresponding product, ( $3 S$, $6 S, 9 S)-\mathbf{5 h},(S, S, R)-\mathbf{5 h}$ or $(S)-\mathbf{7 h}$. It should be noted that the absolute configuration of the bridgehead carbon (C6) is $S$, regardless of the configuration of the vinylglycine residue. The result clearly indicates that the stereogenic center in the 1-aza-5-oxabicyclo[4.3.0] system is the chiral center of the Boc- $(S)$-serine residue, which makes a sharp contrast with the cases of the 1-azabicyclo[4.4.0] as well as 1-azabicyclo[5.4.0] system formation (Schemes 3, 5-8, and 
13). This is partly due to the fact that the 1,3-allylic strain is substantially weakened in the pyrrolidinium ions as compared with the piperidinium ions. The strong directing effect of the Boc- $(S)$-serine residue on the second cyclization via dehydropyrrolidinium ion intermediate $\mathbf{4 h}$-j for the formation of 1-azabicylco[4.3.0] system was further confirmed in the reaction of simple $N$-allylamide of Boc- $(S)$-serine, $(S)$-1 k, which gave $(3 S, 6 S)$-5k and $(3 S, 6 R)-\mathbf{5 k}$ in $92: 8$ ratio (Scheme 13). ${ }^{42}$

The observed strong directing effect of $\mathrm{N}$-Boc- $(S)$-serine residue is rationalized by taking into account the intramolecular hydrogen-bonding between the NH-Boc moiety and the hydroxyl group of the serine residue (see Figure 1 and discussions) as well as the steric conflict associated with $s i$ - and $r e$-attacks of the hydroxyl group at the iminium moiety of $\mathbf{4 k}$. As Figure 2 clearly illustrates, the si-attack (Pro-6S approach) does not have appreciable steric conflict other than a minor 1,3-allylic strain, while the re-attack (Pro-6R approach) suffers from severe steric conflict between the NH-Boc group and the hydrogen of the iminium moiety although there is no 1,3-allylic strain. Thus, the $6 S$-product, $(3 S, 6 S)-\mathbf{5 k}$, is formed as the predominant product.

In conclusion, we have developed a highly efficient method for the synthesis of 1-azabicyclo [x.y.0]alkane amino acid derivatives and their congeners by means of extremely regioselective cyclohydrocarbonylation (CHC) catalyzed by Rh-BIPHEPHOS complex under mild conditions. The reaction involves two consecutive cyclization steps, i.e., the first cyclization to form the cyclic $\mathrm{N}$-acyliminium key intermediate $\mathbf{4}$ via $\mathrm{CHC}$ and the second cyclization to yield the corresponding 1-azabicyclo[x.y.0] system $\mathbf{5}$ with extremely high diastereoselectivity in most cases. The mechanism of the reactions, the rationale for the extremely high diastereoselectivity, and the key factors governing the stereochemistry of the second cyclization are discussed in detail. We believe this catalytic synthetic method is applicable to the syntheses of a variety of restrained dipeptide units, peptidomimetics, alkaloids and other biologically active natural or unnatural products.

\section{Experimental Section}

\section{General Methods and Materials}

See Supporting Information.

\section{General procedure for the preparation of unsaturated dipeptide derivatives 1}

Unsaturated dipeptide or amide substrates 1 were prepared according to the standard peptide coupling method using 1-ethyl-3-(dimethylaminopropyl)carbodiimide (EDC) and 1hydroxybenzotriazol ( $\mathrm{HOBt}$ ). One equivalent of $\mathrm{Et}_{3} \mathrm{~N}$ was used in the case of hydrochlorides. A typical procedure is described for the preparation of $N$-(tert-butoxycarbonyl)-(S)-seryl- $(S)$ allylglycine methyl ester, ${ }^{23}(S, S)$-1a: To a mixture of $N$-t-Boc-L-serine $(103 \mathrm{mg}, 0.50 \mathrm{mmol}$, 1.0 equiv), methyl allylglycinate hydrochloride $(83 \mathrm{mg}, 0.50 \mathrm{mmol}, 1.0$ equiv), EDC (106 $\mathrm{mg}$, $0.55 \mathrm{mmol}, 1.1$ equiv), and $\mathrm{HOBt}$ (102 mg, $0.75 \mathrm{mmol}, 1.5$ equiv) in $\mathrm{CH}_{2} \mathrm{Cl}_{2}(1.0 \mathrm{~mL})$ was added $\mathrm{Et}_{3} \mathrm{~N}(701 / 4 \mathrm{~L}, 0.5 \mathrm{mmol}, 1.0$ equiv) in an ice bath under nitrogen. After the addition was complete, the ice bath was removed. The reaction mixture was allowed to warm up to room temperature and stirred overnight $(\sim 16 \mathrm{~h})$ under nitrogen. The reaction mixture was partitioned with EtOAc $(15 \mathrm{~mL})$ and aqueous $\mathrm{NaHCO}_{3}(0.5 \mathrm{~N}, 25 \mathrm{~mL})$. The resulting aqueous solution was extracted with EtOAc $(15 \mathrm{~mL} \times 2)$. The combined organic layers were washed with saturated $\mathrm{NH}_{4} \mathrm{Cl}(25 \mathrm{~mL})$, brine $(15 \mathrm{~mL})$, dried over $\mathrm{MgSO}_{4}$, and then concentrated under a reduced pressure to give crude residue. The residue was purified by flash chromatography on silica gel, using EtOAc/ $n$-hexane as eluant to afford $(S, S)-\mathbf{1 a}(120 \mathrm{mg}, 76 \%$ yield $)$ as colorless liquid. Characterization data for all substrates 1a-k are summarized in the Supporting Information. 


\section{General procedure of cyclohydrocarbonylation}

A typical procedure is described for the synthesis of $(3 S, 6 S, 10 S)$-1-aza-3-tertbutoxycarbonylamino-10-methoxycarbonyl-5-oxa-2-oxobicyclo[4.4.0]decane, $(3 S, 6 S$, 10S)-5a: To a $10 \mathrm{~mL}$ round-bottomed reaction flask were placed $\mathrm{Rh}(\mathrm{acac})(\mathrm{CO})_{2}(1.9 \mathrm{mg}$, $0.0073 \mathrm{mmol}, 2 \mathrm{~mol} \%$ ) and BIPHEPHOS (11.6 $\mathrm{mg}, 0.0148 \mathrm{mmol}, 4 \mathrm{~mol} \%)$. The atmosphere of the reaction flask was replaced with nitrogen, followed by the addition of degassed toluene $(1.0 \mathrm{~mL})$. The resulting solution was allowed to stir until it became homogeneous. The dipeptide substrate $(S, S)-\mathbf{1 a}(120 \mathrm{mg}, 0.363 \mathrm{mmol})$ and PTSA $(7 \mathrm{mg}, 0.036 \mathrm{mmol})$ were placed in a $25 \mathrm{~mL}$ reaction flask. The catalyst solution was transferred to the reaction flask via syringe, and total volume was adjusted to $6.0 \mathrm{~mL}(0.06 \mathrm{M})$. The reaction flask was placed in a $300 \mathrm{~mL}$ stainless steel autoclave, and the autoclave was flushed with $\mathrm{CO}$ several times. Then, the autoclave was filled with $2 \mathrm{~atm}$ of $\mathrm{CO}$, followed by $2 \mathrm{~atm}$ of $\mathrm{H}_{2}$. The autoclave was heated at $65^{\circ} \mathrm{C}$ with stirring for $20-24 \mathrm{~h}$. Then, the autoclave was cooled to room temperature and gasses were slowly and carefully released. The reaction mixture was then concentrated under reduced pressure to give viscous oil. The crude oily product was purified by flash column chromatography on silica gel, using EtOAc/n-hexane as eluant to give $(3 S, 6 S, 10 S)$-5a $(120$ $\mathrm{mg}, 96 \%$ yield) as colorless oil: ${ }^{1} \mathrm{H}-\mathrm{NMR}\left(400 \mathrm{MHz}, 25{ }^{\circ} \mathrm{C}, \mathrm{CDCl}_{3}\right) \delta 1.38(\mathrm{~s}, 9 \mathrm{H}), 1.47-1.57$ $(\mathrm{m}, 1 \mathrm{H}), 1.65-1.79(\mathrm{~m}, 2 \mathrm{H}), 1.84-2.01(\mathrm{~m}, 3 \mathrm{H}), 3.68(\mathrm{~s}, 3 \mathrm{H}), 3.75(\mathrm{dd}, J=10.2,7.0 \mathrm{~Hz}, 1 \mathrm{H})$, $4.16(\mathrm{dd}, J=10.2,6.2 \mathrm{~Hz}, 1 \mathrm{H}), 4.39-4.44(\mathrm{~m}, 2 \mathrm{H}), 4.93(\mathrm{dd}, J=8.4,4.4 \mathrm{~Hz}, 1 \mathrm{H}), 5.36(\mathrm{~d}, J=$ $6.0 \mathrm{~Hz}, 1 \mathrm{H}) ;{ }^{13} \mathrm{C}-\mathrm{NMR}\left(100 \mathrm{MHz}, 25^{\circ} \mathrm{C}, \mathrm{CDCl}_{3}\right) \delta 16.5,24.5,28.0,28.2,49.8,52.4,54.0$, 67.0, 80.0, 82.7, 155.4, 168.4, 171.5. HRMS-FAB $(\mathrm{m} / \mathrm{z}):[\mathrm{M}+\mathrm{H}]^{+}$calcd for $\mathrm{C}_{15} \mathrm{H}_{24} \mathrm{~N}_{2} \mathrm{O}_{6} \cdot \mathrm{H}^{+}$, 329.1713; found, 329.1713. ( $\Delta=0.0 \mathrm{ppm}$ ).

In the same manner, other reactions were carried out to give the corresponding 1-azabicyclic products $\mathbf{5}$. The characterization data for $\mathbf{5 a}-\mathbf{k}$ are shown below:

\section{(3S,6R,10R)-1-Aza-3-tert-butoxycarbonylamino-10-methoxycarbonyl-5-oxa-2-oxobicyclo [4.4.0]- decane, $(3 S, 6 R, 10 R)-5 a$}

Colorless oil; $90 \%$ yield: ${ }^{1} \mathrm{H}-\mathrm{NMR}\left(400 \mathrm{MHz}, 25{ }^{\circ} \mathrm{C}, \mathrm{CDCl}_{3}\right) \delta 1.31-1.41(\mathrm{~m}, 1 \mathrm{H}), 1.39-1.49$ $(\mathrm{m}, 1 \mathrm{H}), 1.40(\mathrm{~s}, 9 \mathrm{H}), 1.57-1.67(\mathrm{~m}, 1 \mathrm{H}), 1.71-1.77(\mathrm{~m}, 1 \mathrm{H}), 1.92-1.99(\mathrm{~m}, 1 \mathrm{H}), 2.16-2.23(\mathrm{~m}$, $1 \mathrm{H}), 3.69(\mathrm{~s}, 3 \mathrm{H}), 3.98-4.02(\mathrm{~m}, 2 \mathrm{H}), 4.25(\mathrm{brs}, 1 \mathrm{H}), 4.90(\mathrm{dd}, J=10.2,3.4 \mathrm{~Hz}, 1 \mathrm{H}), 5.23(\mathrm{~d}$, $J=7.2 \mathrm{~Hz}, 1 \mathrm{H}), 5.33(\mathrm{~d}, J=5.2 \mathrm{~Hz}, 1 \mathrm{H}) ;{ }^{13} \mathrm{C}-\mathrm{NMR}\left(100 \mathrm{MHz}, 25^{\circ} \mathrm{C}, \mathrm{CDCl}_{3}\right) \delta 19.0,26.1$, $28.3,31.4,50.9,52.2,52.5,68.2,80.1,85.1,155.2,166.5,171.1$. HRMS-FAB $(\mathrm{m} / \mathrm{z}):[\mathrm{M}+$ $\mathrm{H}]^{+}$calcd for $\mathrm{C}_{15} \mathrm{H}_{24} \mathrm{~N}_{2} \mathrm{O}_{6} \cdot \mathrm{H}^{+}, 329.1713$; found, 329.1713. ( $\Delta=0.0 \mathrm{ppm}$ ).

\section{(3S,6R,10S)-1-Aza-10-benzyloxymethyl-3-tert-butoxycarbonylamino-5-oxa-2-oxobicyclo [4.4.0]- decane, $(3 S, 6 R, 10 S)-5 b$}

Colorless oil; $82 \%$ yield; ${ }^{1} \mathrm{H}-\mathrm{NMR}\left(600 \mathrm{MHz}, 25^{\circ} \mathrm{C}, \mathrm{CDCl}_{3}\right) \delta 1.39-1.45(\mathrm{~m}, 1 \mathrm{H}), 1.42(\mathrm{~s}, 9 \mathrm{H})$, $1.54-1.60(\mathrm{~m}, 1 \mathrm{H}), 1.66-1.68(\mathrm{~m}, 2 \mathrm{H}), 1.84(\mathrm{~d}, J=13.8 \mathrm{~Hz}, 1 \mathrm{H}), 1.93$ (ddd, $J=12.6,1.8,1.8$ $\mathrm{Hz} 1 \mathrm{H}), 3.45-3.46(\mathrm{~m}, 1 \mathrm{H}), 3.48-3.51(\mathrm{~m}, 1 \mathrm{H}), 3.55(\mathrm{t}, J=7.8 \mathrm{~Hz} 1 \mathrm{H}), 4.14$ (quintet, $J=6.0$ $\mathrm{Hz}, 1 \mathrm{H}), 4.37-4.43(\mathrm{~m}, 1 \mathrm{H}), 4.50(\mathrm{~m}, 2 \mathrm{H}), 4.80(\mathrm{dd}, J=10.8,3.0 \mathrm{~Hz}, 1 \mathrm{H}), 4.86$ (quartet, $J=$ $6.0 \mathrm{~Hz}, 1 \mathrm{H}), 5.24$ (brs, $1 \mathrm{H}), 7.25-7.34(\mathrm{~m}, 5 \mathrm{H}) ;{ }^{13} \mathrm{C}-\mathrm{NMR}\left(100 \mathrm{MHz}, 25{ }^{\circ} \mathrm{C}, \mathrm{CDCl}_{3}\right) \delta 18.3$, 25.4, 28.5, 32.5, 48.9, 50.5, 67.0, 69.2, 73.2, 80.0, 85.7, 127.8, 127.9, 128.6, 138.4, 156.1, 167.1. HRMS-FAB $(\mathrm{m} / \mathrm{z}):[\mathrm{M}+\mathrm{H}]^{+}$calcd for $\mathrm{C}_{21} \mathrm{H}_{30} \mathrm{~N}_{2} \mathrm{O}_{5} \cdot \mathrm{H}^{+}$, 391.2234; found, 391.2244 $(\Delta=2.5 \mathrm{ppm})$.

\section{(3R,6R,10S)-1-Aza-10-benzyloxymethyl-3-tert-butoxycarbonylamino-5-oxa-2-oxobicyclo} [4.4.0]- decane, $(3 R, 6 R, 10 S)-5 b$

Colorless oil; 80\% yield; ${ }^{1} \mathrm{H}-\mathrm{NMR}\left(600 \mathrm{MHz}, 25^{\circ} \mathrm{C}, \mathrm{CDCl}_{3}\right) \delta 1.42(\mathrm{~s}, 9 \mathrm{H}), 1.42-1.49(\mathrm{~m}$, $1 \mathrm{H}), 1.54-1.60(\mathrm{~m}, 1 \mathrm{H}), 1.66-1.72(\mathrm{~m}, 2 \mathrm{H}), 1.80(\mathrm{~d}, J=13.8 \mathrm{~Hz}, 1 \mathrm{H}), 1.92(\mathrm{dd}, J=12.6,3.0$ $\mathrm{Hz}, 1 \mathrm{H}), 3.48-3.51(\mathrm{~m}, 1 \mathrm{H}), 3.55(\mathrm{t}, J=7.8 \mathrm{~Hz}, 1 \mathrm{H}), 3.86(\mathrm{dd}, J=12.6,3.6 \mathrm{~Hz}, 1 \mathrm{H}), 3.95(\mathrm{~d}$, 
$J=12.0 \mathrm{~Hz}, 1 \mathrm{H}), 4.18(\mathrm{brs}, 1 \mathrm{H}), 4.46(\mathrm{~d}, J=12.0 \mathrm{~Hz}, 1 \mathrm{H}), 4.48(\mathrm{~d}, J=12.0 \mathrm{~Hz}, 1 \mathrm{H}), 4.79(\mathrm{dd}$, $J=10.8,3.0 \mathrm{~Hz}, 1 \mathrm{H}), 4.98$ (quartet, $J=6.0 \mathrm{~Hz}, 1 \mathrm{H}), 5.27$ (brs, $1 \mathrm{H}), 7.25-7.33(\mathrm{~m}, 5 \mathrm{H}) ;{ }^{13} \mathrm{C}-$ NMR $\left(100 \mathrm{MHz}, 25^{\circ} \mathrm{C}, \mathrm{CDCl}_{3}\right) \delta 18.5,25.5,28.5,32.1,48.4,51.2,67.5,69.6,73.2,80.2$, 84.7, 127.8, 127.9, 128.6, 138.2, 155.7, 165.7. HRMS-FAB $(\mathrm{m} / \mathrm{z}):[\mathrm{M}+\mathrm{H}]^{+}$calcd for $\mathrm{C}_{21} \mathrm{H}_{30} \mathrm{~N}_{2} \mathrm{O}_{5} \bullet \mathrm{H}^{+}, 391.2234$; found, 391.2242 ( $\left.\Delta=2.0 \mathrm{ppm}\right)$.

\section{(3S,7S,11S)-1-Aza-3-tert-butoxycarbonylamino-11-methoxycarbonyl-2-oxo-6-oxabicyclo [5.4.0]- undecane, $(3 S, 7 S, 11 S 1)-5 \mathrm{c}$}

Colorless oil; 87\% yield; ${ }^{1} \mathrm{H}-\mathrm{NMR}\left(500 \mathrm{MHz}, 25{ }^{\circ} \mathrm{C}, \mathrm{C}_{6} \mathrm{D}_{6}\right) \delta 0.95$ (ddddd, $J=13.2,9.6,4.8$, $4.8,4.8 \mathrm{~Hz}, 1 \mathrm{H}$ ), 1.06 (dddd, $J=12.5,12.5,4.5,4.5 \mathrm{~Hz}, 1 \mathrm{H}$ ), 1.17 (dddd, $J=15.0,13.0,7.0$, $4.0 \mathrm{~Hz}, 1 \mathrm{H}), 1.35-1.45(\mathrm{~m}, 1 \mathrm{H}), 1.45-1.55(\mathrm{~m}, 1 \mathrm{H}), 1.46(\mathrm{~s}, 9 \mathrm{H}), 1.80(\mathrm{dd}, J=14.0,2.0 \mathrm{~Hz}$, $1 \mathrm{H}), 2.09-2.17(\mathrm{~m}, 2 \mathrm{H}), 3.27(\mathrm{~s}, 3 \mathrm{H}), 3.50(\mathrm{ddd}, J=12.0,12.0,1.5 \mathrm{~Hz}, 1 \mathrm{H}), 3.77$ (ddd, $J=$ $12.0,7.0,3.5 \mathrm{~Hz}, 1 \mathrm{H}), 4.36$ (brs, $1 \mathrm{H}), 4.73$ (ddd, $J=11.5,6.3,2.0 \mathrm{~Hz}, 1 \mathrm{H}), 5.15$ (dd, $J=7.5$, $2.0 \mathrm{~Hz}, 1 \mathrm{H}), 6.20(\mathrm{~d}, J=5.5 \mathrm{~Hz}, 1 \mathrm{H}) ;{ }^{13} \mathrm{C}-\mathrm{NMR}\left(100 \mathrm{MHz}, 25{ }^{\circ} \mathrm{C}, \mathrm{C}_{6} \mathrm{D}_{6}\right) \delta 15.9,25.6,28.8$, $30.9,33.8,52.0,52.8,53.5,70.4,79.4,82.9,155.7,171.9,175.1$. HRMS-FAB $(\mathrm{m} / z):[\mathrm{M}+$ $\mathrm{H}]^{+}$calcd for $\mathrm{C}_{16} \mathrm{H}_{26} \mathrm{~N}_{2} \mathrm{O}_{6} \cdot \mathrm{H}^{+}, 343.1869$; found, $343.1869(\Delta=0.0 \mathrm{ppm})$.

(3S,6S,10S)-1,5-Diaza-3-tert-butoxycarbonylamino-5-tert-butoxycarbonyl-10methoxycarbonyl-2-oxobicyclo[4.4.0]decane, $(3 S, 6 S, 10 S)-5 \mathrm{~d}$

Colorless oil; $95 \%$ yield: ${ }^{1} \mathrm{H}-\mathrm{NMR}\left(400 \mathrm{MHz}, 25^{\circ} \mathrm{C}, \mathrm{CDCl}_{3}\right) \delta 1.41(\mathrm{~s}, 9 \mathrm{H}), 1.49(\mathrm{~s}, 9 \mathrm{H})$, $1.65-2.02(\mathrm{~m}, 6 \mathrm{H}), 3.03(\mathrm{t}, J=12.0 \mathrm{~Hz}, 1 \mathrm{H}), 3.71(\mathrm{~s}, 3 \mathrm{H}), 3.74(\mathrm{~m}, 1 \mathrm{H}), 4.01$ (ddd, $J=10.8$, $4.8,4.8 \mathrm{~Hz}, 1 \mathrm{H}), 4.60$ (brs, $1 \mathrm{H}), 5.30$ (brs, $1 \mathrm{H}), 5.47$ (brs, $1 \mathrm{H}) ;{ }^{13} \mathrm{C}-\mathrm{NMR}\left(100 \mathrm{MHz}, 25^{\circ} \mathrm{C}\right.$, $\left.\mathrm{CDCl}_{3}\right) \delta 21.5,24.5,28.3,29.6,41.7,50.3,52.2,59.8,68.5,79.8(2 \mathrm{C}), 81.8,153.2,155.4$, 167.8, 169.5. HRMS-FAB $(\mathrm{m} / \mathrm{z}):[\mathrm{M}+\mathrm{H}]^{+}$calcd for $\mathrm{C}_{20} \mathrm{H}_{33} \mathrm{~N}_{3} \mathrm{O}_{7} \bullet \mathrm{H}^{+}, 428.2397$; found, 428.2398. $(\Delta=0.2 \mathrm{ppm})$.

\section{(3R,6S,10S)-1-Aza-3-benzyloxycarbonylamino-10-methoxycarbonyl-2-oxo-6-thiabicyclo [4.4.0]- decane, $(3 R, 6 S, 10 S)-5 e$}

The reaction of $(R, S)-\mathbf{1 e}(195 \mathrm{mg}, 0.32 \mathrm{mmol})$ was carried out in $\mathrm{MeOH}$ in place of toluene and in the absence of PTSA, but otherwise under the same conditions as the standard procedure described above, to give $N$-benzyloxycarbonyl- $S$-trityl- $(R)$-cysteinyl- $(S)$-6-oxonorleucine methyl ester $[(R, S)-2 \mathrm{e}](180 \mathrm{mg}, 86 \%$ yield $)$ as colorless oil; ${ }^{1} \mathrm{H}-\mathrm{NMR}\left(400 \mathrm{MHz}, 25^{\circ} \mathrm{C}\right.$, $\left.\mathrm{CDCl}_{3}\right) \delta 1.52-1.68(\mathrm{~m}, 3 \mathrm{H}), 1.75-1.86(\mathrm{~m}, 1 \mathrm{H}), 2.34-2.39(\mathrm{~m}, 2 \mathrm{H}), 2.53(\mathrm{dd}, J=13.2,5.6 \mathrm{~Hz}$, $1 \mathrm{H}), 2.79(\mathrm{dd}, J=13.2,7.2 \mathrm{~Hz}, 1 \mathrm{H}), 3.67(\mathrm{~s}, 3 \mathrm{H}), 3.85(\mathrm{brs}, 1 \mathrm{H}) ; 4.48-4.54(\mathrm{~m}, 1 \mathrm{H}), 5.03(\mathrm{~d}$, $J=13.2 \mathrm{~Hz}, 1 \mathrm{H}), 5.07(\mathrm{~d}, J=13.2 \mathrm{~Hz}, 1 \mathrm{H}), 5.28(\mathrm{~d}, J=6.8 \mathrm{~Hz}, 1 \mathrm{H}), 6.58(\mathrm{~d}, J=6.8 \mathrm{~Hz}, 1 \mathrm{H})$, 7.17-7.41 (m, 20H), $9.63(\mathrm{t}, J=1.2 \mathrm{~Hz}, 1 \mathrm{H}) ;{ }^{13} \mathrm{C}$ NMR $\left(100 \mathrm{MHz}, 25^{\circ} \mathrm{C}, \mathrm{CDCl}_{3}\right) \delta 17.5,31.3$, $33.7,42.8,51.7,52.3,53.8,66.9,67.1,126.8,127.9,127.9,128.0,128.3,129.4,136.0,144.2$, $155.7,169.9,171.7,201.4$.

$(R, S)$-2e $(139 \mathrm{mg}, 0.216 \mathrm{mmol})$ was dissolved in dichloromethane $(1.0 \mathrm{~mL})$. To this solution was added trifluoracetic acid (TFA) $(1 \mathrm{~mL})$ at room temperature. The reaction mixture was poured into saturated $\mathrm{NaHCO}_{3}(3 \mathrm{~mL})$ and extracted with EtOAc $(5 \mathrm{~mL} \times 3)$. The combined extracts were washed with brine, dried over $\mathrm{MgSO}_{4}$, filtered and evaporated. The crude product was purified by flash chromatography on silica gel using EtOAc/n-hexane as eluant to afford $(3 R, 6 S, 10 S)-5 e(72 \mathrm{mg}, 87 \%)$ as colorless oil: ${ }^{1} \mathrm{H}-\mathrm{NMR}\left(400 \mathrm{MHz}, 25^{\circ} \mathrm{C}, \mathrm{CDCl}_{3}\right) \delta 1.50-1.60$ $(\mathrm{m}, 1 \mathrm{H}), 1.62-1.82(\mathrm{~m}, 1 \mathrm{H}), 1.70-1.80(\mathrm{~m}, 1 \mathrm{H}), 1.84-1.90(\mathrm{~m}, 1 \mathrm{H}), 1.94-2.04(\mathrm{~m}, 1 \mathrm{H}), 2.16-2.26$ (m, 1H), 2.69 (dd, $J=12.0,10.5 \mathrm{~Hz}, 1 \mathrm{H}), 3.55(\mathrm{dd}, J=10.5,6.0 \mathrm{~Hz}, 1 \mathrm{H}), 3.70(\mathrm{~s}, 3 \mathrm{H}), 4.69$ (ddd, $J=12.0,6.0,6.0 \mathrm{~Hz}, 1 \mathrm{H}), 4.88(\mathrm{dd}, J=7.2,3.6 \mathrm{~Hz}, 1 \mathrm{H}), 5.04-5.14(\mathrm{~m}, 1 \mathrm{H}), 5.09(\mathrm{~s}, 2 \mathrm{H})$, $6.13(\mathrm{~d}, J=6.0 \mathrm{~Hz}, 1 \mathrm{H}), 7.25-7.35(\mathrm{~m}, 5 \mathrm{H}) ;{ }^{13} \mathrm{C}-\mathrm{NMR}\left(100 \mathrm{MHz}, 25^{\circ} \mathrm{C}, \mathrm{CDCl}_{3}\right) \delta 17.2,24.6$, 27.8, 29.0, 51.5, 52.4, 53.1, 53.5, 66.9, 127.9, 128.0, 128.4, 136.2, 155.5, 170.9, 171.5. HRMSFAB $(m / z):[\mathrm{M}+\mathrm{H}]^{+}$calcd for $\mathrm{C}_{18} \mathrm{H}_{22} \mathrm{~N}_{2} \mathrm{O}_{5} \mathrm{~S} \bullet \mathrm{H}^{+}, 379.1327$; found, $379.1328(\Delta=0.2 \mathrm{ppm})$. 
(3S,7S,11S)-1-Aza-3-benzyloxycarbonylamino-11-methoxycarbonyl-2-oxo-6-thiabicyclo [5.4.0]- undecane, $(3 S, 7 S, 11 S)-5 f$

The reaction of $(S, S)$-1f was carried out in the same manner as that for $(R, S)$-1e. Thus, the hydroformylation of $(S, S)$-1f in MeOH gave $(S, S)-\mathbf{2 f}(520 \mathrm{mg}, 93 \%)$ as colorless oil: ${ }^{1} \mathrm{H}-\mathrm{NMR}$ $\left(400 \mathrm{MHz}, 25^{\circ} \mathrm{C}, \mathrm{CDCl}_{3}\right) \delta 1.57(\mathrm{~m}, 4 \mathrm{H}), 1.77(\mathrm{~m}, 2 \mathrm{H}), 2.29(\mathrm{~m}, 2 \mathrm{H}), 2.39(\mathrm{~m}, 2 \mathrm{H}), 3.71(\mathrm{~s}$, $3 \mathrm{H}), 4.12(\mathrm{~m}, 1 \mathrm{H}) ; 4.49(\mathrm{dd}, J=7.6 ; 13.2 \mathrm{~Hz}, 1 \mathrm{H}), 5.05(\mathrm{~d}, J=12.4 \mathrm{~Hz}, 1 \mathrm{H}), 5.09(\mathrm{~d}, J=12.4$ $\mathrm{Hz}, 1 \mathrm{H}), 5.15(\mathrm{~d}, J=8.0 \mathrm{~Hz}, 1 \mathrm{H}), 5.59(\mathrm{~d}, J=7.6 \mathrm{~Hz}, 1 \mathrm{H}), 7.16-7.40(\mathrm{~m}, 20 \mathrm{H}), 9.68(\mathrm{t}, J=$ $1.2 \mathrm{~Hz}, 1 \mathrm{H}) ;{ }^{13} \mathrm{C} \mathrm{NMR}\left(100 \mathrm{MHz}, 2{ }^{\circ} \mathrm{C}, \mathrm{CDCl}_{3}\right) \delta 17.9,28.2,31.7,31.8,43.2,52.1,52.7$, $54.3,67.2,67.3,126.9,128.2,128.3,128.4,128.8,129.8,136.4,144.9,156.3,171.3,172.3$, 201.8 .

Then, $(S, S)$-2f $(53 \mathrm{mg}, 0.07 \mathrm{mmol})$ was dissolved in benzene $(0.5 \mathrm{~mL})$ containing $1 \%(\mathrm{v} / \mathrm{v})$ methanesulfonic acid $(\mathrm{MsOH})$ at room temperature. To this solution was added trifluoracetic acid (TFA) $(0.4 \mathrm{~mL})$ followed by $\mathrm{Et}_{3} \mathrm{SiH}(101 / 4 \mathrm{~L})$ in an ice bath. The reaction immediately gave a precipitate of triphenylmethane. Fitration of the precipitate and concentration gave a crude product, which was purified by flash chromatography on silica gel using EtOAc/nhexane as eluant to afford $(3 S, 7 S, 11 S)-5 f(27 \mathrm{mg})$ in $90 \%$ yield as colorless oil: ${ }^{1} \mathrm{H}-\mathrm{NMR}$ (400 $\left.\mathrm{MHz}, 50{ }^{\circ} \mathrm{C}, \mathrm{CDCl}_{3}\right) \delta 1.14-1.22(\mathrm{~m}, 1 \mathrm{H}), 1.50-1.60(\mathrm{~m}, 1 \mathrm{H}), 1.55-1.65(\mathrm{~m}, 1 \mathrm{H}), 1.76-1.84$ $(\mathrm{m}, 1 \mathrm{H}), 2.05-2.25(\mathrm{~m}, 1 \mathrm{H}), 2.05-2.25(\mathrm{~m}, 1 \mathrm{H}), 2.05-2.25(\mathrm{~m}, 1 \mathrm{H}), 2.38-2.46(\mathrm{~m}, 1 \mathrm{H}), 2.50-2.58$ $(\mathrm{m}, 1 \mathrm{H}), 2.61-2.70(\mathrm{~m}, 1 \mathrm{H}), 3.77(\mathrm{~s}, 3 \mathrm{H}), 4.37(\mathrm{t}, J=5.0 \mathrm{~Hz}, 1 \mathrm{H}), 5.02(\mathrm{~d}, J=6.5 \mathrm{~Hz}, 1 \mathrm{H})$, 5.10-5.20 (m, 1H), 5.11-5.32 (m, 3H), 7.25-7.35 (m, 5H); ${ }^{13} \mathrm{C}-\mathrm{NMR}\left(100 \mathrm{MHz}, 2{ }^{\circ} \mathrm{C}\right.$, $\left.\mathrm{CDCl}_{3}\right) \delta 19.4,20.3,26.5,32.8,36.8,51.4,52.9,58.1,67.9,69.8,128.4,128.7,128.9,135.9$, 154.7, 168.2, 170.6. HRMS-FAB $(\mathrm{m} / \mathrm{z}):[\mathrm{M}+\mathrm{H}]^{+}$calcd for $\mathrm{C}_{19} \mathrm{H}_{24} \mathrm{~N}_{2} \mathrm{O}_{5} \mathrm{~S} \bullet \mathrm{H}^{+}, 393.1484$; found, $393.1482(\Delta=0.5 \mathrm{ppm})$.

(3S,4R,6S,10S)-1-Aza-3-tert-butoxycarbonylamino-10-methoxycarbonyl-4-methyl-5-oxa-2oxobicyclo[4.4.0]decane, (3S,4R,6S,10S)-5g

Colorless oil; 85\% yield; ${ }^{1} \mathrm{H}-\mathrm{NMR}\left(400 \mathrm{MHz}, 25^{\circ} \mathrm{C}, \mathrm{CDCl}_{3}\right) \delta 1.21(\mathrm{~d}, J=6.0 \mathrm{~Hz}, 3 \mathrm{H}), 1.44$ $(\mathrm{s}, 9 \mathrm{H}), 1.52-1.58(\mathrm{~m}, 1 \mathrm{H}), 1.66-1.72(\mathrm{~m}, 1 \mathrm{H}), 1.74-1.81(\mathrm{~m}, 1 \mathrm{H}), 1.95-2.00(\mathrm{~m}, 2 \mathrm{H}), 1.97-2.03$ $(\mathrm{m}, 1 \mathrm{H}), 3.72(\mathrm{~s}, 3 \mathrm{H}), 4.27(\mathrm{dq}, J=6.0,5.0 \mathrm{~Hz}, 1 \mathrm{H}), 4.41(\mathrm{t}, J=7.0 \mathrm{~Hz}, 1 \mathrm{H}) 4.45(\mathrm{dd}, J=8.0$, $5.0 \mathrm{~Hz}, 1 \mathrm{H}), 4.92(\mathrm{dd}, J=10.0,4.5 \mathrm{~Hz}, 1 \mathrm{H}), 5.25(\mathrm{~d}, J=8.0 \mathrm{~Hz}, 1 \mathrm{H}) ;{ }^{13} \mathrm{C}-\mathrm{NMR}(100 \mathrm{MHz}$, $\left.25^{\circ} \mathrm{C}, \mathrm{CDCl}_{3}\right) \delta 16.5,17.0,24.7,28.3,28.4,52.4,53.4,53.8,72.6,80.0,82.7,155.6,168.1$, 171.7. HRMS-FAB $(\mathrm{m} / \mathrm{z})$ : $[\mathrm{M}+\mathrm{H}]^{+}$calcd for $\mathrm{C}_{16} \mathrm{H}_{26} \mathrm{~N}_{2} \mathrm{O}_{2} \bullet \mathrm{H}^{+}$, 343.1870; found, 343.1868 $(\Delta=0.6 \mathrm{ppm})$.

(3R,4R,6R,10S)-1-Aza-3-tert-butoxycarbonylamino-10-methoxycarbonyl-4-methyl-5-oxa-2oxobicyclo[4.4.0]decane, (3R,4R,6R,10S)-5g

Colorless oil; 94\% yield; ${ }^{1} \mathrm{H}-\mathrm{NMR}\left(500 \mathrm{MHz}, 25^{\circ} \mathrm{C}, \mathrm{CDCl}_{3}\right) \delta 1.43(\mathrm{~d}, J=7.0 \mathrm{~Hz}, 3 \mathrm{H})$, $1.43-1.50(\mathrm{~m}, 1 \mathrm{H}), 1.46(\mathrm{~s}, 9 \mathrm{H}), 1.59(\mathrm{dq}, J=13.0,3.0 \mathrm{~Hz}, 1 \mathrm{H}), 1.66$ (dddd, $J=14.0,14.0$, 6.0, $4.0 \mathrm{~Hz}, 1 \mathrm{H}), 1.82-1.86(\mathrm{~m}, 1 \mathrm{H}), 1.90-1.94(\mathrm{~m}, 1 \mathrm{H}), 2.23-2.26(\mathrm{~m}, 1 \mathrm{H}), 3.75(\mathrm{~s}, 3 \mathrm{H})$, 4.01-4.08 (m, 1H), 4.12 (quintet, $J=6.0 \mathrm{~Hz}, 1 \mathrm{H}), 5.08(\mathrm{dd}, J=10.5,3.0 \mathrm{~Hz}, 1 \mathrm{H}), 5.17(\mathrm{~d}, J=$ $7.0 \mathrm{~Hz}, 1 \mathrm{H}), 5.43(\mathrm{~d}, J=6.0 \mathrm{~Hz}, 1 \mathrm{H}) ;{ }^{13} \mathrm{C}-\mathrm{NMR}\left(100 \mathrm{MHz}, 25^{\circ} \mathrm{C}, \mathrm{CDCl}_{3}\right) \delta 17.1,19.7,26.2$, 28.4, 31.3, 52.6 (2 C), 55.6, 71.4, 80.1, 80.7, 155.8, 167.0, 171.3. HRMS-FAB $(\mathrm{m} / \mathrm{z}):[\mathrm{M}+$ $\mathrm{H}]^{+}$calcd for $\mathrm{C}_{16} \mathrm{H}_{26} \mathrm{~N}_{2} \mathrm{O}_{6} \cdot \mathrm{H}^{+}, 343.1870$; found, $343.1884(\Delta=4.1 \mathrm{ppm})$.

\section{(3S,4S,6S,10S)-1-Aza-3-tert-butoxycarbonylamino-10-methoxycarbonyl-4-methyl-5-oxa-2- oxobicyclo[4.4.0]decane, (3S,4S,6S,10S)-5g}

Colorless oil, 69\% yield: ${ }^{1} \mathrm{H}-\mathrm{NMR}\left(500 \mathrm{MHz}, 25^{\circ} \mathrm{C}, \mathrm{CDCl}_{3}\right) \delta 1.34(\mathrm{~d}, J=5.5 \mathrm{~Hz}, 3 \mathrm{H}), 1.41$ (s, 9H), 1.46-1.53 (m, 1H), 1.67-1.78 (m, 2H), 1.85-1.94 (m, 2H), 1.99- 2.06 (m, 1H), $3.70(\mathrm{~s}$, $3 \mathrm{H}), 3.78(\mathrm{dq}, J=10.0,6.0 \mathrm{~Hz}, 1 \mathrm{H}), 4.31(\mathrm{t}, J=8.5 \mathrm{~Hz}, 1 \mathrm{H}), 4.48(\mathrm{t}, J=6.0 \mathrm{~Hz}, 1 \mathrm{H}), 5.12$ $(\mathrm{dd}, J=7.0,5.5 \mathrm{~Hz}, 1 \mathrm{H}), 5.15(\mathrm{~d}, J=6.5 \mathrm{~Hz}, 1 \mathrm{H}) ;{ }^{13} \mathrm{C}-\mathrm{NMR}\left(100 \mathrm{MHz}, 25^{\circ} \mathrm{C}, \mathrm{CDCl}_{3}\right) \delta 16.7$, 
19.2, 24.7, 28.3 (C-7 and $t$-Bu), 52.48, 53.96, 55.1, 72.5, 79.1, 80.1, 156.2, 170.2, 171.8.

HRMS-FAB $(m / z):[\mathrm{M}+\mathrm{H}]^{+}$calcd for $\mathrm{C}_{16} \mathrm{H}_{26} \mathrm{~N}_{2} \mathrm{O}_{6} \cdot \mathrm{H}^{+}, 343.1870$; found, $343.1878(\Delta=2.3$ ppm).

(3S,4S,6R,10S)-1-Aza-3-tert-butoxycarbonylamino-10-methoxycarbonyl-4-methyl-5-oxa-2oxobicyclo[4.4.0]decane, (3S,4S,6R,10S)-5g

Clolorless oil; $17 \%$ yield; ${ }^{1} \mathrm{H}-\mathrm{NMR}\left(500 \mathrm{MHz}, 25{ }^{\circ} \mathrm{C}, \mathrm{CDCl}_{3}\right) \delta 1.30-1.36(\mathrm{~m}, 1 \mathrm{H}), 1.33(\mathrm{~d}$, $J=6.0 \mathrm{~Hz}, 3 \mathrm{H}), 1.39-1.47$ (m, 1H), $1.42(\mathrm{~s}, 9 \mathrm{H}), 1.65$ (dddd, $J=13.5,13.5,6.5,4.0 \mathrm{~Hz}, 1 \mathrm{H})$, $1.75(\mathrm{dq}, J=13.0,3.0 \mathrm{~Hz}, 1 \mathrm{H}), 1.94$ (dddd, $J=13.0,10.0,3.5,1.5 \mathrm{~Hz}, 1 \mathrm{H}), 2.19$ (dq, $J=14.0$, $1.5 \mathrm{~Hz}, 1 \mathrm{H}), 3.70(\mathrm{~s}, 3 \mathrm{H}), 3.77$ (dddd, $J=10.0,6.0,6.0,6.0 \mathrm{~Hz}, 1 \mathrm{H}), 4.04-4.11(\mathrm{~m}, 1 \mathrm{H}), 4.87$ (brs, $1 \mathrm{H}), 4.98(\mathrm{dd}, J=11.0,3.0 \mathrm{~Hz}, 1 \mathrm{H}), 5.18(\mathrm{~d}, J=6.0 \mathrm{~Hz}, 1 \mathrm{H}) ;{ }^{13} \mathrm{C}-\mathrm{NMR}(100 \mathrm{MHz}, 25$ $\left.{ }^{\circ} \mathrm{C}, \mathrm{CDCl}_{3}\right) \delta 19.1,19.5,26.3,28.5,31.8,52.6,53.1,56.1,74.7,80.1,85.4,156.6,169.1,171.6$. HRMS-FAB $(m / z):[\mathrm{M}+\mathrm{H}]^{+}$calcd for $\mathrm{C}_{16} \mathrm{H}_{26} \mathrm{~N}_{2} \mathrm{O}_{6} \cdot \mathrm{H}^{+}, 343.1870$; found, $343.1883(\Delta=3.8$ ppm).

(3R,4S,6R,10S)-1-Aza-3-tert-butoxycarbonylamino-10-methoxycarbonyl-4-methyl-5-oxa-2oxobicyclo[4.4.0]decane, (3R,4S,6R,10S)-5g

Colorless oil; 78\% yield; ${ }^{1} \mathrm{H}-\mathrm{NMR}\left(500 \mathrm{MHz}, 25^{\circ} \mathrm{C}, \mathrm{CDCl}_{3}\right) \delta 1.15(\mathrm{~d}, J=6.0 \mathrm{~Hz}, 3 \mathrm{H})$, $1.27-1.33(\mathrm{~m}, 1 \mathrm{H}), 1.32-1.40(\mathrm{~m}, 1 \mathrm{H}), 1.36(\mathrm{~s}, 9 \mathrm{H}), 1.54-1.60(\mathrm{~m}, 1 \mathrm{H}), 1.66-1.72(\mathrm{~m}, 1 \mathrm{H})$, $1.88-1.94(\mathrm{~m}, 1 \mathrm{H}), 2.14-2.18(\mathrm{~m}, 1 \mathrm{H}), 3.64(\mathrm{~s}, 3 \mathrm{H}), 3.96-4.02(\mathrm{~m}, 1 \mathrm{H}), 4.21(\mathrm{~d}, J=10.0 \mathrm{~Hz}$, $1 \mathrm{H}), 4.87(\mathrm{~d}, J=6.0 \mathrm{~Hz}, 1 \mathrm{H}), 4.97(\mathrm{~d}, J=10.0 \mathrm{~Hz}, 1 \mathrm{H}), 5.24(\mathrm{~d}, J=5.0 \mathrm{~Hz}, 1 \mathrm{H}) ;{ }^{13} \mathrm{C}-\mathrm{NMR}$ $\left(100 \mathrm{MHz}, 25^{\circ} \mathrm{C}, \mathrm{CDCl}_{3}\right) \delta 15.8,19.4,26.3,28.4,31.8,52.1,52.6,54.3,73.6,80 ., 85.1,155.8$, 167.2, 171.3. HRMS-FAB $(\mathrm{m} / \mathrm{z}):[\mathrm{M}+\mathrm{H}]^{+}$calcd for $\mathrm{C}_{16} \mathrm{H}_{26} \mathrm{~N}_{2} \mathrm{O}_{6} \cdot \mathrm{H}^{+}, 343.1870$; found, $343.1868(\Delta=0.6 \mathrm{ppm})$.

(3R,4S,6S,10S)-1-Aza-3-tert-butoxycarbonylamino-10-methoxycarbonyl-4-methyl-5-oxa-2oxobicyclo[4.4.0]decane, (3R,4S,6S,10S)-5g

Colorless oil; $10 \%$ yield; ${ }^{1} \mathrm{H}-\mathrm{NMR}\left(500 \mathrm{MHz}, 25^{\circ} \mathrm{C}, \mathrm{CDCl}_{3}\right) \delta 1.18(\mathrm{~d}, J=7.0 \mathrm{~Hz}, 3 \mathrm{H}), 1.40$ (s, 9H), 1.46-1.55 (m, 1H), 1.67-1.77 (m, 2H), 1.83-1.91 (m, 2H), 1.90-1.97 (m, 1H), $3.72(\mathrm{~s}$, $3 \mathrm{H}), 4.46$ (brs, $1 \mathrm{H}), 4.71-4.78(\mathrm{~m}, 1 \mathrm{H}), 4.72(\mathrm{dd}, J=11.0,3.0 \mathrm{~Hz}, 1 \mathrm{H}), 5.34(\mathrm{dd}, J=11.0,4.0$ $\mathrm{Hz}, 1 \mathrm{H}), 5.45$ (brs, $1 \mathrm{H}) ;{ }^{13} \mathrm{C}-\mathrm{NMR}\left(100 \mathrm{MHz}, 25^{\circ} \mathrm{C}, \mathrm{CDCl}_{3}\right) \delta 12.9,20.0,27.5,28.5,30.5$, 52.5, 54.2, 56.7, 70.5, 80.1, 81.3, 155.8, 169.3, 171.5. HRMS-FAB $(\mathrm{m} / \mathrm{z}):[\mathrm{M}+\mathrm{H}]^{+}$calcd for $\mathrm{C}_{16} \mathrm{H}_{26} \mathrm{~N}_{2} \mathrm{O}_{6} \cdot \mathrm{H}^{+}, 343.1870$; found, 343.1869 ( $\left.\Delta=0.3 \mathrm{ppm}\right)$.

(3S,6S,9R)-1-Aza-3-tert-butoxycarbonylamino-9-methoxycarbonyl-5-oxa-2-ox-bicyclo [4.3.0]- nonane, $(3 S, 6 S, 9 R)-5 \mathrm{~h}$

Colorless needles (from $n$-heptane); $21 \%$ yield; mp $139-141{ }^{\circ} \mathrm{C} ;{ }^{1} \mathrm{H}$-NMR $\left(500 \mathrm{MHz}, 25{ }^{\circ} \mathrm{C}\right.$, $\left.\mathrm{CDCl}_{3}\right) \delta 1.41(\mathrm{~s}, 9 \mathrm{H}), 1.88-1.98(\mathrm{~m}, 2 \mathrm{H}), 2.23-2.33(\mathrm{~m}, 2 \mathrm{H}), 3.64(\mathrm{dd}, J=10.0,7.0 \mathrm{~Hz}, 1 \mathrm{H})$, $3.70(\mathrm{~s}, 3 \mathrm{H}), 4.36(\mathrm{t}, J=10.0 \mathrm{~Hz}, 1 \mathrm{H}), 4.41-4.46(\mathrm{~m}, 1 \mathrm{H}), 4.72(\mathrm{dd}, J=8.0,5.0 \mathrm{~Hz}, 1 \mathrm{H}), 5.21$ $(\mathrm{dd}, J=5.5,4.5 \mathrm{~Hz}, 1 \mathrm{H}), 5.49$ (brs, $1 \mathrm{H}) ;{ }^{13} \mathrm{C}-\mathrm{NMR}\left(100 \mathrm{MHz}, 25^{\circ} \mathrm{C}, \mathrm{CDCl}_{3}\right) \delta 26.3,28.5$, $31.7,49.3,52.8,58.2,68.9,80.4,87.6,155.9,166.8,171.6$. HRMS-FAB $(m / z):[\mathrm{M}+\mathrm{Na}]^{+}$ calcd for $\mathrm{C}_{14} \mathrm{H}_{22} \mathrm{~N}_{2} \mathrm{O}_{6} \cdot \mathrm{Na}^{+}, 315.1556$; found, 315.1545 ( $\Delta=3.5 \mathrm{ppm}$ ).

(3S,6S,9S)-1-Aza-3-tert-butoxycarbonylamino-9-methoxycarbonyl-5-oxa-2-oxobicyclo [4.3.0]- nonane, (3S,6S,9S)-5h

Colorless oil; $48 \%$ yield; $[\alpha]_{\mathrm{D}}{ }^{21}-22^{\circ}\left(c 0.37, \mathrm{CHCl}_{3}\right) ;{ }^{1} \mathrm{H}-\mathrm{NMR}\left(500 \mathrm{MHz}, 25^{\circ} \mathrm{C}, \mathrm{CDCl}_{3}\right) \delta$ $1.39(\mathrm{~s}, 9 \mathrm{H}), 1.93-2.01(\mathrm{~m}, 1 \mathrm{H}), 2.04-2.12(\mathrm{~m}, 1 \mathrm{H}), 2.06-2.17(\mathrm{~m}, 1 \mathrm{H}), 2.23-2.28(\mathrm{~m}, 1 \mathrm{H}), 3.70$ (s, 3H), $3.81(\mathrm{dd}, J=9.0,6.5 \mathrm{~Hz}, 1 \mathrm{H}), 4.29(\mathrm{dd}, J=9.0,8.0 \mathrm{~Hz}, 1 \mathrm{H}), 4.32-4.37(\mathrm{~m}, 1 \mathrm{H}), 4.40$ $(\mathrm{dd}, J \mathrm{~Hz}, 1 \mathrm{H}), 4.87(\mathrm{~d}, J=6.0 \mathrm{~Hz}, 1 \mathrm{H}), 4.97(\mathrm{~d}, J=10.0 \mathrm{~Hz}, 1 \mathrm{H}), 5.24(\mathrm{~d}, J=5.0 \mathrm{~Hz}$, $1 \mathrm{H}) ;{ }^{13} \mathrm{C}-\mathrm{NMR}\left(100 \mathrm{MHz}, 25^{\circ} \mathrm{C}, \mathrm{CDCl}_{3}\right) \delta 15.8,19.4,26.3,28.4,31.8,52.1,52.6,54.3,73.6$, 
80., 85.1, 155.8, 167.2, 171.3. HRMS-FAB $(\mathrm{m} / z):[\mathrm{M}+\mathrm{H}]^{+}$calcd for $\mathrm{C}_{16} \mathrm{H}_{26} \mathrm{~N}_{2} \mathrm{O}_{6} \cdot \mathrm{H}^{+}$, 343.1870; found, $343.1868(\Delta=0.6 \mathrm{ppm})$.

(3R,4S,6S,10S)-1-Aza-3-tert-butoxycarbonylamino-10-methoxycarbonyl-4-methyl-5-oxa-2oxobicyclo[4.4.0]decane, $(3 R, 4 S, 6 S, 10 S)-5 \mathrm{~g}$

Colorless oil; $10 \%$ yield; $1 \mathrm{H}-\mathrm{NMR}\left(500 \mathrm{MHz}, 25^{\circ} \mathrm{C}, \mathrm{CDCl}_{3}\right) \delta 1.18(\mathrm{~d}, J=7.0 \mathrm{~Hz}, 3 \mathrm{H}), 1.40$ $(\mathrm{s}, 9 \mathrm{H}), 1.46-1.55(\mathrm{~m}, 1 \mathrm{H}), 1.67-1.77(\mathrm{~m}, 2 \mathrm{H}), 1.83-1.91(\mathrm{~m}, 2 \mathrm{H}), 1.90-1.97(\mathrm{~m}, 1 \mathrm{H}), 3.72(\mathrm{~s}$, $3 \mathrm{H}), 4.46$ (brs, 1H), 4.71-4.78 (m, 1H), 4.72 (dd, $J=11.0,3.0 \mathrm{~Hz}, 1 \mathrm{H}), 5.34$ (dd, $J=11.0,4.0$ $\mathrm{Hz}, 1 \mathrm{H}), 5.45$ (brs, $1 \mathrm{H}) ;{ }^{13} \mathrm{C}-\mathrm{NMR}\left(100 \mathrm{MHz}, 2{ }^{\circ} \mathrm{C}, \mathrm{CDCl}_{3}\right) \delta 12.9,20.0,27.5,28.5,30.5$, 52.5, 54.2, 56.7, 70.5, 80.1, 81.3, 155.8, 169.3, 171.5. HRMS-FAB $(\mathrm{m} / \mathrm{z}):[\mathrm{M}+\mathrm{H}]^{+}$calcd for $\mathrm{C}_{16} \mathrm{H}_{26} \mathrm{~N}_{2} \mathrm{O}_{6} \cdot \mathrm{H}^{+}, 343.1870$; found, $343.1869(\Delta=0.3 \mathrm{ppm})$.

(3S,6S,9R)-1-Aza-3-tert-butoxycarbonylamino-9-methoxycarbonyl-5-oxa-2-oxobicyclo [4.3.0]- nonane, $(3 S, 6 S, 9 R)-5 \mathrm{~h}$

Colorless needles (from $n$-heptane); $21 \%$ yield; mp $139-141{ }^{\circ} \mathrm{C} ;{ }^{1} \mathrm{H}-\mathrm{NMR}\left(500 \mathrm{MHz}, 25{ }^{\circ} \mathrm{C}\right.$, $\left.\mathrm{CDCl}_{3}\right) \delta 1.41(\mathrm{~s}, 9 \mathrm{H}), 1.88-1.98(\mathrm{~m}, 2 \mathrm{H}), 2.23-2.33(\mathrm{~m}, 2 \mathrm{H}), 3.64(\mathrm{dd}, J=10.0,7.0 \mathrm{~Hz}, 1 \mathrm{H})$, $3.70(\mathrm{~s}, 3 \mathrm{H}), 4.36(\mathrm{t}, J=10.0 \mathrm{~Hz}, 1 \mathrm{H}), 4.41-4.46(\mathrm{~m}, 1 \mathrm{H}), 4.72(\mathrm{dd}, J=8.0,5.0 \mathrm{~Hz}, 1 \mathrm{H}), 5.21$ (dd, $J=5.5,4.5 \mathrm{~Hz}, 1 \mathrm{H}), 5.49$ (brs, $1 \mathrm{H}) ;{ }^{13} \mathrm{C}-\mathrm{NMR}\left(100 \mathrm{MHz}, 25^{\circ} \mathrm{C}, \mathrm{CDCl}_{3}\right) \delta 26.3,28.5$, $31.7,49.3,52.8,58.2,68.9,80.4,87.6,155.9,166.8,171.6 . \operatorname{HRMS}-\mathrm{FAB}(\mathrm{m} / \mathrm{z}):[\mathrm{M}+\mathrm{Na}]^{+}$ calcd for $\mathrm{C}_{14} \mathrm{H}_{22} \mathrm{~N}_{2} \mathrm{O}_{6} \cdot \mathrm{Na}^{+}, 315.1556$; found, 315.1545 ( $\Delta=3.5 \mathrm{ppm}$ ).

(3S,6S,9S)-1-Aza-3-tert-butoxycarbonylamino-9-methoxycarbonyl-5-oxa-2-oxobicyclo [4.3.0]- nonane, $(3 S, 6 S, 9 S)-5 \mathrm{~h}$

Colorless oil; $48 \%$ yield; $[\alpha] \mathrm{D}^{21}-22^{\circ}\left(c 0.37, \mathrm{CHCl}_{3}\right) ;{ }^{1} \mathrm{H}-\mathrm{NMR}\left(500 \mathrm{MHz}, 2{ }^{\circ} \mathrm{C}, \mathrm{CDCl}_{3}\right) \delta$ $1.39(\mathrm{~s}, 9 \mathrm{H}), 1.93-2.01(\mathrm{~m}, 1 \mathrm{H}), 2.04-2.12(\mathrm{~m}, 1 \mathrm{H}), 2.06-2.17(\mathrm{~m}, 1 \mathrm{H}), 2.23-2.28(\mathrm{~m}, 1 \mathrm{H}), 3.70$ (s, 3H), $3.81(\mathrm{dd}, J=9.0,6.5 \mathrm{~Hz}, 1 \mathrm{H}), 4.29(\mathrm{dd}, J=9.0,8.0 \mathrm{~Hz}, 1 \mathrm{H}), 4.32-4.37(\mathrm{~m}, 1 \mathrm{H}), 4.40$ (dd, $J=8.0,1.0 \mathrm{~Hz}, 1 \mathrm{H}), 5.17$ (dd, $J=7.0,6.0 \mathrm{~Hz}, 1 \mathrm{H}), 5.49$ (brs, $1 \mathrm{H}) ;{ }^{13} \mathrm{C}-\mathrm{NMR}(100 \mathrm{MHz}$, $\left.25^{\circ} \mathrm{C}, \mathrm{CDCl}_{3}\right) \delta 26.5,28.4,30.9,49.4,52.7,57.9,69.3,80.3,88.0,156.0,166.8,171.3$. HRMSFAB $(\mathrm{m} / z):[\mathrm{M}+\mathrm{Na}]^{+}$calcd for $\mathrm{C}_{14} \mathrm{H}_{22} \mathrm{~N}_{2} \mathrm{O}_{6} \cdot \mathrm{Na}^{+}, 315.1556$; found, $315.1551(\Delta=1.6 \mathrm{ppm})$.

(3R,6R,9S)-1-Aza-3-tert-butoxycarbonylamino-9-methoxycarbonyl-5-oxa-2-oxobicyclo [4.3.0]- nonane, $(3 R, 6 R, 9 S)-5 \mathrm{~h}$

White needle (from $n$-heptane); $42 \%$ yield; mp $141-142{ }^{\circ} \mathrm{C} ;{ }^{1} \mathrm{H}$-NMR $\left(400 \mathrm{MHz}, 25^{\circ} \mathrm{C}\right.$, $\left.\mathrm{CDCl}_{3}\right) \delta 1.41(\mathrm{~s}, 9 \mathrm{H}), 1.88-1.98(\mathrm{~m}, 2 \mathrm{H}), 2.23-2.33(\mathrm{~m}, 2 \mathrm{H}), 3.64(\mathrm{dd}, J=10.0,7.0 \mathrm{~Hz}, 1 \mathrm{H})$, $3.70(\mathrm{~s}, 3 \mathrm{H}), 4.36(\mathrm{t}, J=10 \mathrm{~Hz}, 1 \mathrm{H}), 4.41-4.46(\mathrm{~m}, 1 \mathrm{H}), 4.72(\mathrm{dd}, J=8.0,5.0 \mathrm{~Hz}, 1 \mathrm{H}), 5.21$ (dd, $J=5.5,4.5 \mathrm{~Hz}, 1 \mathrm{H}), 5.49$ (brs, $1 \mathrm{H}) ;{ }^{13} \mathrm{C}-\mathrm{NMR}\left(100 \mathrm{MHz}, 25{ }^{\circ} \mathrm{C}, \mathrm{CDCl}_{3}\right) \delta 26.3,28.5$, $31.7,49.3,52.8,58.2,68.9,80.4,87.6,155.9,166.8,171.6$. HRMS-FAB $(m / z):[\mathrm{M}+\mathrm{Na}]^{+}$ calcd for $\mathrm{C}_{14} \mathrm{H}_{22} \mathrm{~N}_{2} \mathrm{O}_{6} \cdot \mathrm{Na}^{+}, 315.1556$; found, 315.1545 ( $\Delta=3.5 \mathrm{ppm}$ ).

(3R,6R,9R)-1-Aza-3-tert-butoxycarbonylamino-9-methoxycarbonyl-5-oxa-2-oxobicyclo [4.3.0]- nonane, $(3 R, 6 R, 9 R)-5 \mathrm{~h}$

Colorless oil; $16 \%$ yield; $[\alpha]_{\mathrm{D}}{ }^{21}+22^{\circ}\left(c 0.27, \mathrm{CHCl}_{3}\right) ;{ }^{1} \mathrm{H}-\mathrm{NMR}\left(400 \mathrm{MHz}, 2{ }^{\circ} \mathrm{C}, \mathrm{CDCl}_{3}\right) \delta$ $1.39(\mathrm{~s}, 9 \mathrm{H}), 1.93-2.01(\mathrm{~m}, 1 \mathrm{H}), 2.04-2.12(\mathrm{~m}, 1 \mathrm{H}), 2.06-2.17(\mathrm{~m}, 1 \mathrm{H}), 2.23-2.28(\mathrm{~m}, 1 \mathrm{H}), 3.70$ (s, 3H), $3.81(\mathrm{dd}, J=9.0,6.5 \mathrm{~Hz}, 1 \mathrm{H}), 4.29(\mathrm{dd}, J=9.0,8.0 \mathrm{~Hz}, 1 \mathrm{H}), 4.32-4.37(\mathrm{~m}, 1 \mathrm{H}), 4.40$ (dd, $J=8.0,1.0 \mathrm{~Hz}, 1 \mathrm{H}), 5.17$ (dd, $J=7.0,6.0 \mathrm{~Hz}, 1 \mathrm{H}), 5.49$ (brs, $1 \mathrm{H}) ;{ }^{13} \mathrm{C}-\mathrm{NMR}(100 \mathrm{MHz}$, $\left.25^{\circ} \mathrm{C}, \mathrm{CDCl}_{3}\right) \delta 26.5,28.4,30.9,49.4,52.7,57.9,69.3,80.3,88.0,156.0,166.8,171.3$. HRMSFAB $(m / z):[\mathrm{M}+\mathrm{Na}]^{+}$calcd for $\mathrm{C}_{14} \mathrm{H}_{22} \mathrm{~N}_{2} \mathrm{O}_{6} \cdot \mathrm{Na}^{+}, 315.1556$; found, 315.1551 ( $\left.\Delta=1.6 \mathrm{ppm}\right)$. 
(3S,6S,9R)-1-Aza-9-benzyloxymethyl-3-tert-butoxycarbonylamino-5-oxa-2-oxobicyclo [4.3.0]- nonane, $(3 S, 6 S, 9 R)-5 i$

Colorless oil; 87\% yield; ${ }^{1} \mathrm{H}-\mathrm{NMR}\left(500 \mathrm{MHz}, 25^{\circ} \mathrm{C}, \mathrm{CDCl}_{3}\right) \delta 1.43(\mathrm{~s}, 9 \mathrm{H}), 1.79-1.85(\mathrm{~m}$, $1 \mathrm{H}), 1.83-1.91(\mathrm{~m}, 1 \mathrm{H}), 2.02-2.10(\mathrm{~m}, 1 \mathrm{H}), 2.27-2.34(\mathrm{~m}, 1 \mathrm{H}), 3.52(\mathrm{dd}, J=9.5,3.0 \mathrm{~Hz}, 1 \mathrm{H})$, $3.56(\mathrm{dd}, J=9.5,5.0 \mathrm{~Hz}, 1 \mathrm{H}), 3.61(\mathrm{dd}, J=9.5,6.0 \mathrm{~Hz}, 1 \mathrm{H}), 4.30(\mathrm{t}, J=8.0 \mathrm{~Hz}, 1 \mathrm{H}), 4.31-4.38$ (m, 1H), 4.38-4.43 (m, 1H), $4.46(\mathrm{~d}, J=12.0 \mathrm{~Hz}, 1 \mathrm{H}), 4.49$ (d, $J=12.0 \mathrm{~Hz}, 1 \mathrm{H}), 5.06$ (dd, $J$ $=6.0,3.5 \mathrm{~Hz}, 1 \mathrm{H}), 5.45(\mathrm{brs}, 1 \mathrm{H}), 7.24-7.34(\mathrm{~m}, 5 \mathrm{H}) ;{ }^{13} \mathrm{C}-\mathrm{NMR}\left(100 \mathrm{MHz}, 25{ }^{\circ} \mathrm{C}, \mathrm{CDCl}_{3}\right)$ $\delta$ 24.6, 28.5, 31.8, 49.5, 57.3, 68.7, 71.0, 73.5, 80.4, 87.9, 127.8, 127.9, 128.6, 138.4, 156.1, 166.8. HRMS-FAB $(\mathrm{m} / z)$ : $[\mathrm{M}+\mathrm{Na}]^{+}$calcd for $\mathrm{C}_{20} \mathrm{H}_{28} \mathrm{~N}_{2} \mathrm{O}_{5} \cdot \mathrm{Na}^{+}$, 399.1896; found, 399.1908 $(\Delta=3.0 \mathrm{ppm})$.

(3R,6R,9R)-1-Aza-9-benzyloxymethyl-3-tert-butoxycarbonylamino-5-oxa-2-oxobicyclo [4.3.0]- nonane, $(3 R, 6 R, 9 R)-5 \mathrm{i}$

Colorless oil; $42 \%$ yield; ${ }^{1} \mathrm{H}-\mathrm{NMR}\left(500 \mathrm{MHz}, 25{ }^{\circ} \mathrm{C}, \mathrm{CDCl}_{3}\right) \delta 1.43(\mathrm{~s}, 9 \mathrm{H}), 1.94$ (dddd, $J=$ 12.0, 12.0, 7.0, 7.0 Hz, 1H), 1.98-2.07 (m, 1H), $2.13(\mathrm{dd}, J=12.0,1.5 \mathrm{~Hz}, 1 \mathrm{H}), 2.21$ (quintet, $J=6.0 \mathrm{~Hz}, 1 \mathrm{H}), 3.52(\mathrm{dd}, J=9.5,3.0 \mathrm{~Hz}, 1 \mathrm{H}), 3.56(\mathrm{dd}, J=9.5,5.0 \mathrm{~Hz}, 1 \mathrm{H}), 3.58(\mathrm{t}, J=8.5$ $\mathrm{Hz}, 1 \mathrm{H}), 4.36-4.44(\mathrm{~m}, 3 \mathrm{H}), 4.46(\mathrm{~d}, J=12.0 \mathrm{~Hz}, 1 \mathrm{H}), 4.49(\mathrm{~d}, J=12.0 \mathrm{~Hz}, 1 \mathrm{H}), 5.16(\mathrm{t}, J=$ $6.5 \mathrm{~Hz}, 1 \mathrm{H}), 5.45$ (brs, $1 \mathrm{H}) .7 .24-7.36(\mathrm{~m}, 5 \mathrm{H}) ;{ }^{13} \mathrm{C}-\mathrm{NMR}\left(100 \mathrm{MHz}, 25{ }^{\circ} \mathrm{C}, \mathrm{CDCl}_{3}\right) \delta 25.5$, 28.5, 30.6, 49.4, 56.7, 68.4, 68.6, 73.5, 80.3, 87.2, 127.7, 127.8, 128.6, 138.4, 156.0, 166.6. HRMS-FAB $(\mathrm{m} / z):[\mathrm{M}+\mathrm{Na}]^{+}$calcd for $\mathrm{C}_{20} \mathrm{H}_{28} \mathrm{~N}_{2} \mathrm{O}_{5} \cdot \mathrm{Na}^{+}$, 399.1896; found, $399.1909(\Delta=$ $3.3 \mathrm{ppm})$.

(3R,6S,9R)-1-Aza-9-benzyloxymethyl-3-tert-butoxycarbonylamino-5-oxa-2-oxobicyclo [4.3.0]- nonane, $(3 R, 6 S, 9 R)-5 i$

Colorless oil; $41 \%$ yield; ${ }^{1} \mathrm{H}-\mathrm{NMR}\left(600 \mathrm{MHz}, 25^{\circ} \mathrm{C}, \mathrm{CDCl}_{3}\right) \delta 1.41(\mathrm{~s}, 9 \mathrm{H}), 1.66-1.73(\mathrm{~m}$, $1 \mathrm{H}), 1.84-1.90(\mathrm{~m}, 1 \mathrm{H}), 1.99-2.04(\mathrm{~m}, 1 \mathrm{H}), 2.17-2.21(\mathrm{~m}, 1 \mathrm{H}), 3.53(\mathrm{dd}, J=9.6,2.4 \mathrm{~Hz}, 1 \mathrm{H})$, $3.64(\mathrm{t}, J=10.8 \mathrm{~Hz}, 1 \mathrm{H}), 3.74$ (dd, $J=9.6,4.2 \mathrm{~Hz}, 1 \mathrm{H}), 4.04$ (brs, $1 \mathrm{H}$ ), 4.27 (brs, $1 \mathrm{H}$ ), 4.43 (brs, $1 \mathrm{H}), 4.46(\mathrm{~d}, J=12.0 \mathrm{~Hz}, 1 \mathrm{H}), 4.49(\mathrm{~d}, J=12.6 \mathrm{~Hz}, 1 \mathrm{H}), 5.03(\mathrm{dd}, J=8.4,6.5 \mathrm{~Hz}, 1 \mathrm{H})$, $5.11(\mathrm{~d}, J=6.0 \mathrm{~Hz}, 1 \mathrm{H}), 7.24-7.36(\mathrm{~m}, 5 \mathrm{H}) ;{ }^{13} \mathrm{C}-\mathrm{NMR}\left(100 \mathrm{MHz}, 2{ }^{\circ} \mathrm{C}, \mathrm{CDCl}_{3}\right) \delta 22.7,28.5$, $31.4,49.9,56.0,69.2,70.7,73.4,80.2,90.1,127.7,127.8,128.6,138.5,156.1$, 166.7. HRMSFAB $(m / z):[\mathrm{M}+\mathrm{Na}]^{+}$calcd for $\mathrm{C}_{20} \mathrm{H}_{28} \mathrm{~N}_{2} \mathrm{O}_{5} \cdot \mathrm{Na}^{+}, 399.1896$; found, $399.1909(\Delta=3.3 \mathrm{ppm})$.

(3S,6S,9S)-1-Aza-3-tert-butoxycarbonylamino-9-methyl-5-oxa-2-oxobicyclo[4.3.0]nonane, $(3 S, 6 S, 9 S)-5 j$

Colorless needles (from $n$-heptane); $94 \%$ yield; mp 121-122 ${ }^{\circ} \mathrm{C} ;{ }^{1} \mathrm{H}$-NMR $\left(500 \mathrm{MHz}, 25{ }^{\circ} \mathrm{C}\right.$, $\left.\mathrm{CDCl}_{3}\right) \delta 1.21(\mathrm{~d}, J=6.0 \mathrm{~Hz}, 3 \mathrm{H}), 1.40(\mathrm{~s}, 9 \mathrm{H}), 1.44(\mathrm{~m}, 1 \mathrm{H}), 1.80$ (dddd, $J=15.0,7.5,7.5$, $4.5 \mathrm{~Hz}, 1 \mathrm{H}), 2.10$ (dddd, $J=14.0,7.5,7.5,7.5 \mathrm{~Hz}, 1 \mathrm{H}), 2.22$ (dddd, $J=13.5,7.0,7.0,6.5 \mathrm{~Hz}$, $1 \mathrm{H}), 3.61(\mathrm{dd}, J=9.0,6.0 \mathrm{~Hz}, 1 \mathrm{H}), 4.23(\operatorname{sixtet}, J=6.5 \mathrm{~Hz}, 1 \mathrm{H}), 4.30(\mathrm{~m}, 2 \mathrm{H}), 5.05(\mathrm{dd}, J=$ 5.5, 5.0 Hz, 1H), 5.50 (brs, $1 \mathrm{H}) ;{ }^{13} \mathrm{C}-\mathrm{NMR}\left(100 \mathrm{MHz}, 2{ }^{\circ} \mathrm{C}, \mathrm{CDCl}_{3}\right) \delta 20.7,28.5,29.4,31.2$, 49.5, 53.7, 68.9, 80.2, 87.4, 156.1, 166.6. HRMS-FAB $(\mathrm{m} / \mathrm{z}):[\mathrm{M}+\mathrm{Na}]^{+}$calcd for $\mathrm{C}_{13} \mathrm{H}_{22} \mathrm{~N}_{2} \mathrm{O}_{4} \cdot \mathrm{Na}^{+}$, 293.1477; found, 293.1499 ( $\left.\Delta=7.5 \mathrm{ppm}\right)$.

(3R,6R,9S)-1-Aza-3-tert-butoxycarbonylamino-9-methyl-5-oxa-2-oxobicyclo[4.3.0]nonane, $(3 R, 6 R, 9 S)-5 j$

Colorless oil; $45 \%$ yield; ${ }^{1} \mathrm{H}-\mathrm{NMR}\left(600 \mathrm{MHz}, 25^{\circ} \mathrm{C}, \mathrm{CDCl}_{3}\right) \delta 1.31(\mathrm{~d}, J=6.6 \mathrm{~Hz}, 3 \mathrm{H}), 1.41$ (s, 9H), 1.65-1.70 (m, 1H), 1.92-2.01 (m, 2H), 2.19-2.22 (m, 1H), $3.54(\mathrm{t}, J=9.0 \mathrm{~Hz}, 1 \mathrm{H}), 4.09$ (quintet, $J=6.6 \mathrm{~Hz}, 1 \mathrm{H}), 4.32(\mathrm{q}, J=7.8 \mathrm{~Hz}, 1 \mathrm{H}), 4.40(\mathrm{t}, J=9.0 \mathrm{~Hz}, 1 \mathrm{H}), 5.10(\mathrm{t}, J=6.3 \mathrm{~Hz}$, 1H), 5.49 (brs, $1 \mathrm{H}) ;{ }^{13} \mathrm{C}-\mathrm{NMR}\left(100 \mathrm{MHz}, 25^{\circ} \mathrm{C}, \mathrm{CDCl}_{3}\right) \delta 19.2,28.5,29.6,30.3,49.3,53.2$, 68.5, 80.3, 87.2, 156.1, 166.2. HRMS-FAB $(\mathrm{m} / \mathrm{z}):[\mathrm{M}+\mathrm{Na}]^{+}$calcd for $\mathrm{C}_{13} \mathrm{H}_{22} \mathrm{~N}_{2} \mathrm{O}_{4} \bullet \mathrm{Na}^{+}$, 293.1477; found, $293.1494(\Delta=5.8 \mathrm{ppm})$. 
(3R,6S,9R)-1-Aza-9-benzyloxymethyl-3-tert-butoxycarbonylamino-5-oxa-2oxobicyclo[4.3.0]-nonane, $(3 R, 6 S, 9 R)-5 \mathrm{i}$

Colorless oil; $41 \%$ yield; ${ }^{1} \mathrm{H}-\mathrm{NMR}\left(600 \mathrm{MHz}, 25{ }^{\circ} \mathrm{C}, \mathrm{CDCl}_{3}\right) \delta 1.41(\mathrm{~s}, 9 \mathrm{H}), 1.66-1.73(\mathrm{~m}$, $1 \mathrm{H}), 1.84-1.90(\mathrm{~m}, 1 \mathrm{H}), 1.99-2.04(\mathrm{~m}, 1 \mathrm{H}), 2.17-2.21(\mathrm{~m}, 1 \mathrm{H}), 3.53(\mathrm{dd}, J=9.6,2.4 \mathrm{~Hz}, 1 \mathrm{H})$, 3.64 (t, $J=10.8 \mathrm{~Hz}, 1 \mathrm{H}), 3.74$ (dd, $J=9.6,4.2 \mathrm{~Hz}, 1 \mathrm{H}$ ), 4.04 (brs, 1H), 4.27 (brs, $1 \mathrm{H}$ ), 4.43 (brs, 1H), $4.46(\mathrm{~d}, J=12.0 \mathrm{~Hz}, 1 \mathrm{H}), 4.49(\mathrm{~d}, J=12.6 \mathrm{~Hz}, 1 \mathrm{H}), 5.03(\mathrm{dd}, J=8.4,6.5 \mathrm{~Hz}, 1 \mathrm{H})$, $5.11(\mathrm{~d}, J=6.0 \mathrm{~Hz}, 1 \mathrm{H}), 7.24-7.36(\mathrm{~m}, 5 \mathrm{H}) ;{ }^{13} \mathrm{C}-\mathrm{NMR}\left(100 \mathrm{MHz}, 2{ }^{\circ} \mathrm{C}, \mathrm{CDCl}_{3}\right) \delta 22.7,28.5$, $31.4,49.9,56.0,69.2,70.7,73.4,80.2,90.1,127.7,127.8,128.6,138.5,156.1,166.7$. HRMSFAB $(\mathrm{m} / z):[\mathrm{M}+\mathrm{Na}]^{+}$calcd for $\mathrm{C}_{20} \mathrm{H}_{28} \mathrm{~N}_{2} \mathrm{O}_{5} \cdot \mathrm{Na}^{+}, 399.1896$; found, $399.1909(\Delta=3.3 \mathrm{ppm})$.

(3S,6S,9S)-1-Aza-3-tert-butoxycarbonylamino-9-methyl-5-oxa-2-oxobicyclo [4.3.0]nonane, $(3 S, 6 S, 9 S)-5 j$

Colorless needles (from $n$-heptane); $94 \%$ yield; mp 121-122 ${ }^{\circ} \mathrm{C} ;{ }^{1} \mathrm{H}$-NMR $\left(500 \mathrm{MHz}, 25{ }^{\circ} \mathrm{C}\right.$, $\left.\mathrm{CDCl}_{3}\right) \delta 1.21(\mathrm{~d}, J=6.0 \mathrm{~Hz}, 3 \mathrm{H}), 1.40(\mathrm{~s}, 9 \mathrm{H}), 1.44(\mathrm{~m}, 1 \mathrm{H}), 1.80$ (dddd, $J=15.0,7.5,7.5$, $4.5 \mathrm{~Hz}, 1 \mathrm{H}$ ), 2.10 (dddd, $J=14.0,7.5,7.5,7.5 \mathrm{~Hz}, 1 \mathrm{H}$ ), 2.22 (dddd, $J=13.5,7.0,7.0,6.5 \mathrm{~Hz}$, $1 \mathrm{H}), 3.61(\mathrm{dd}, J=9.0,6.0 \mathrm{~Hz}, 1 \mathrm{H}), 4.23($ sixtet, $J=6.5 \mathrm{~Hz}, 1 \mathrm{H}), 4.30(\mathrm{~m}, 2 \mathrm{H}), 5.05(\mathrm{dd}, J=$ 5.5, $5.0 \mathrm{~Hz}, 1 \mathrm{H}), 5.50$ (brs, $1 \mathrm{H}) ;{ }^{13} \mathrm{C}-\mathrm{NMR}\left(100 \mathrm{MHz}, 25^{\circ} \mathrm{C}, \mathrm{CDCl}_{3}\right) \delta 20.7,28.5,29.4,31.2$, 49.5, 53.7, 68.9, 80.2, 87.4, 156.1, 166.6. HRMS-FAB $(\mathrm{m} / \mathrm{z}):[\mathrm{M}+\mathrm{Na}]^{+}$calcd for $\mathrm{C}_{13} \mathrm{H}_{22} \mathrm{~N}_{2} \mathrm{O}_{4} \cdot \mathrm{Na}^{+}$, 293.1477; found, 293.1499 ( $\left.\Delta=7.5 \mathrm{ppm}\right)$.

(3R,6R,9S)-1-Aza-3-tert-butoxycarbonylamino-9-methyl-5-oxa-2-oxobicyclo [4.3.0]nonane, $(3 R, 6 R, 9 S)-5 \mathrm{j}$

Colorless oil; $45 \%$ yield; ${ }^{1} \mathrm{H}-\mathrm{NMR}\left(600 \mathrm{MHz}, 25{ }^{\circ} \mathrm{C}, \mathrm{CDCl}_{3}\right) \delta 1.31(\mathrm{~d}, J=6.6 \mathrm{~Hz}, 3 \mathrm{H}), 1.41$ (s, 9H), 1.65-1.70 (m, 1H), 1.92-2.01 (m, 2H), 2.19-2.22 (m, 1H), $3.54(\mathrm{t}, J=9.0 \mathrm{~Hz}, 1 \mathrm{H}), 4.09$ (quintet, $J=6.6 \mathrm{~Hz}, 1 \mathrm{H}), 4.32(\mathrm{q}, J=7.8 \mathrm{~Hz}, 1 \mathrm{H}), 4.40(\mathrm{t}, J=9.0 \mathrm{~Hz}, 1 \mathrm{H}), 5.10(\mathrm{t}, J=6.3 \mathrm{~Hz}$, 1H), 5.49 (brs, $1 \mathrm{H}) ;{ }^{13} \mathrm{C}-\mathrm{NMR}\left(100 \mathrm{MHz}, 25^{\circ} \mathrm{C}, \mathrm{CDCl}_{3}\right) \delta 19.2,28.5,29.6,30.3,49.3,53.2$, 68.5, 80.3, 87.2, 156.1, 166.2. HRMS-FAB $(\mathrm{m} / \mathrm{z}):[\mathrm{M}+\mathrm{Na}]^{+}$calcd for $\mathrm{C}_{13} \mathrm{H}_{22} \mathrm{~N}_{2} \mathrm{O}_{4} \cdot \mathrm{Na}^{+}$, 293.1477; found, $293.1494(\Delta=5.8 \mathrm{ppm})$.

(3R,6S,9S)-1-Aza-3-tert-butoxycarbonylamino-9-methyl-5-oxa-2-oxobicyclo [4.3.0]nonane, $(3 R, 6 S, 9 S)-5$ j

Colorless oil; 34\% yield; ${ }^{1} \mathrm{H}-\mathrm{NMR}\left(600 \mathrm{MHz}, 25^{\circ} \mathrm{C}, \mathrm{CDCl}_{3}\right) \delta 1.28(\mathrm{~d}, J=6.4 \mathrm{~Hz}, 3 \mathrm{H})$, $1.39-1.45(\mathrm{~m}, 1 \mathrm{H}), 1.41(\mathrm{~s}, 9 \mathrm{H}), 1.69-1.76(\mathrm{~m}, 1 \mathrm{H}), 2.16-2.21(\mathrm{~m}, 2 \mathrm{H}), 3.67(\mathrm{t}, J=10.8 \mathrm{~Hz}$, $1 \mathrm{H}$ ), 4.02 (brs, $1 \mathrm{H}), 4.15$ (sixtet, $J=7.0 \mathrm{~Hz}, 1 \mathrm{H}), 4.45$ (brs, $1 \mathrm{H}), 5.03$ (dd, $J=8.8,5.2 \mathrm{~Hz}, 1 \mathrm{H}$ ), 5.49 (brs, $1 \mathrm{H}) ;{ }^{13} \mathrm{C}-\mathrm{NMR}\left(100 \mathrm{MHz}, 25^{\circ} \mathrm{C}, \mathrm{CDCl}_{3}\right) \delta 21.7(2 \mathrm{C}), 28.5,31.4,50.0,52.6,69.3$, 80.3, 89.2, 156.2, 165.7. HRMS-FAB $(\mathrm{m} / z)$ : $[\mathrm{M}+\mathrm{Na}]^{+}$calcd for $\mathrm{C}_{13} \mathrm{H}_{22} \mathrm{~N}_{2} \mathrm{O}_{4} \bullet \mathrm{Na}^{+}, 293.1477$; found, $293.1495(\Delta=6.0 \mathrm{ppm})$.

(3S,6S)-1-Aza-3-tert-butoxycarbonylamino-5-oxa-2-oxobicyclo[4-3.0] nonane, $(S, S)-5 k$

White solid; 70\% yield; mp 104-106 ${ }^{\circ} \mathrm{C},{ }^{1} \mathrm{H}-\mathrm{NMR}\left(500 \mathrm{MHz}, 2{ }^{\circ} \mathrm{C}, \mathrm{CDCl}_{3}\right) \delta 1.41$ (s, 9H), $1.70-1.77(\mathrm{~m}, 1 \mathrm{H}), 1.82-1.88(\mathrm{~m}, 1 \mathrm{H}), 1.89-1.96(\mathrm{~m}, 1 \mathrm{H}), 2.15(\mathrm{ddd}, J=12.0,6.0,6.0,6.0 \mathrm{~Hz}$, $1 \mathrm{H}), 3.26$ (ddd, $J=12.0,7.5,5.5 \mathrm{~Hz}, 1 \mathrm{H}), 3.55(\mathrm{dd}, J=9.0,6.0 \mathrm{~Hz}, 1 \mathrm{H}), 3.73$ (ddd, $J=11.5$, 7.0, 7.0 Hz, 1H), 4.22-4.34 (m, 2H), $5.01(\mathrm{t}, J=5.5 \mathrm{~Hz}, 1 \mathrm{H}), 5.54(\mathrm{~d}, J=4.5 \mathrm{~Hz}, 1 \mathrm{H}) ;{ }^{13} \mathrm{C}-$ NMR (100 MHz, $\left.25^{\circ} \mathrm{C}, \mathrm{CDCl}_{3}\right) \delta 21.4,28.2,32.4,44.8,49.4,68.5,79.3,86.4,156.0,166.2$. HRMS-FAB $(\mathrm{m} / \mathrm{z})$ : $[\mathrm{M}+\mathrm{H}]^{+}$calcd for $\mathrm{C}_{12} \mathrm{H}_{20} \mathrm{~N}_{2} \mathrm{O}_{4} \cdot \mathrm{H}^{+}, 257.1501$; found, $257.1490(\Delta=4.3$ ppm). 


\section{(3S,6R)-1-Aza-3-tert-butoxycarbonylamino-5-oxa-2-oxobicyclo[4.3.0] nonane, $(S, R)-5 \mathrm{k}$}

White solid; $6 \%$ yield; mp 140-142 ${ }^{\circ} \mathrm{C},{ }^{1} \mathrm{H}-\mathrm{NMR}\left(500 \mathrm{MHz}, 25{ }^{\circ} \mathrm{C}, \mathrm{CDCl}_{3}\right) \delta 1.41(\mathrm{~s}, 9 \mathrm{H})$, 1.73-1.85 (m, 2H), 1.94- $2.00(\mathrm{~m}, 1 \mathrm{H}), 2.16-2.23(\mathrm{~m}, 1 \mathrm{H}), 3.41-3.46(\mathrm{~m}, 1 \mathrm{H}), 3.68(\mathrm{ddd}, J=$ $12.0,8.5,8.5 \mathrm{~Hz}, 1 \mathrm{H}), 3.74(\mathrm{t}, J=11.0 \mathrm{~Hz}, 1 \mathrm{H}), 3.93-4.01(\mathrm{~m}, 1 \mathrm{H}), 4.38-4.48(\mathrm{~m}, 1 \mathrm{H}), 5.00-5.05$ (m, 1H), 5.14 (brs, $1 \mathrm{H}) ;{ }^{13} \mathrm{C}-\mathrm{NMR}\left(100 \mathrm{MHz}, 25^{\circ} \mathrm{C}, \mathrm{CDCl}_{3}\right) \delta$ 19.7, 28.5, 31.8, 43.6, 49.8, 69.3, 80.5, 90.0, 156.1, 166.0. HRMS-FAB $(\mathrm{m} / \mathrm{z}):[\mathrm{M}+\mathrm{H}]^{+}$calcd for $\mathrm{C}_{12} \mathrm{H}_{20} \mathrm{~N}_{2} \mathrm{O}_{4} \bullet \mathrm{H}^{+}$, 257.1501; found, $257.1498(\Delta=1.2 \mathrm{ppm})$.

Single crystal X-ray analyses for $(3 S, 6 S, 10 S)-5 d$ (Figure $S 1),(3 S, 6 S, 9 R)-5 h$ (Figure $S 2),(3 R$, 6R,9S)-5h (Figure S3), and (3S,6S,9S)-5j (Figure S4): see Supporting Information.

\section{Supplementary Material}

Refer to Web version on PubMed Central for supplementary material.

\section{ACKNOWLEDGMENT}

This research was supported by grants form the National Institutes of Health (NIGMS) and the National Science Foundation. The authors would like to thank Professor Joseph W. Lauher for X-ray crystallographic analyses, and Dr. James Marecek as well as Mr. Francis Picart for their technical support in 2D and 1D difference NMR analyses at the Department of Chemistry, State University of New York at Stony Brook.

\section{REFERENCES}

1. Cluzeau J, Lubell WD. Peptide Science 2005;80:98-150. [PubMed: 15795926]

2. Maison W, Prenzel AHGP. Synthesis 2005:1031-1048.

3. Hanessian S, Laoui BR. Bioorg. Med. Chem. Lett 1994;4:1397-1400.

4. Genin MJ, Johnson RL. J. Am. Chem. Soc 1992;114:8778-8783.

5. Gramberg D, Robinson JA. Tetrahedron Lett 1994;35:861-864.

6. Sato K, Nagai U. J. Chem. Soc., Perkin Trans 1986;1:1231-1234.

7. Haubner R, Schmitt W, Hölzemann G, Goodman SL, Jonczyk A, Kessler H. J. Am. Chem. Soc 1996;118:7881-7891.

8. Hanessian S, McNaughton-Smith G, Lombart H-G, Lubell WD. Tetrahedron 1997;53:12789-12854.

9. Falorni M, Giacomelli G, Nieddu F, Taddei M. Tetrahedron Lett 1997;38:4663-4666.

10. Robl JA, Cimarusti MP, Simpkins LM, Brown B, Ryono DE, Bird JE, Asaad MM, Schaeffer TR, Trippodo NC. J. Med. Chem 1996;39:494-502. [PubMed: 8558518]

11. Robl JA, Sun C-Q, Stevenson J, Ryono DE, Simpkins LM, Cimarusti MP, Dejneka T, Slusarchyk WA, Chao S, Stratton L, Misra RN, Bednarz MS, Asaad MM, Cheung HS, Abboa-Offei BE, Smith PL, Mathers PD, Fox M, Schaeffer TR, Seymour AA, Trippodo NC. J. Med. Chem 1997;40:15701577. [PubMed: 9171867]

12. Fink CA, Carlson JE, McTaggart PA, Qiao Y, Webb R, Chatelain R, Jeng AY, Trapani AJ. J. Med. Chem 1996;39:3158-3168. [PubMed: 8759637]

13. Flynn, GA. PCT Int. Appl. 1994. WO 9410193 A1

14. Tamura SY, Goldman EA, Brunck TK, Ripka WC, Semple JE. Bioorg. Med. Chem. Lett 1997;7:331336.

15. Wagner J, Kallen J, Ehrhardt C, Evenou J-P, Wagner D. J. Med. Chem 1998;41:3664-3674. [PubMed: 9733491]

16. Nagai U, Sato K. Tetrahedron Lett 1985;26:647-650.

17. Nagai U, Sato K, Nakamura R, Kato R. Tetrahedron 1993;49:3577-3592.

18. Siddiqui MA, Préville P, Tarazi M, Warder SE, Eby P, Gorseth E, Puumala K, DiMaio J. Tetrahedron Lett 1997;38:8807-8810. 
19. Akasaka K, Komatsu Y, Tagami K, Shimizu T, Shimomura N, Naka H, Hayashi K, Negi S. Chem. Pharm. Bull 1999;47:1532-1537.

20. Estiarte MA, Rubiralta M, Diez A. J. Org. Chem 2000;65:6992-6999. [PubMed: 11031021]

21. Robl JA. Tetrahedron Lett 1994;35:393-396.

22. Baldwin JE, Hulme C, Schofield CJ, Edwards AJ. J. Chem. Soc., Chem. Commun 1993;11:935-936.

23. Mizutani N, Chiou W-H, Ojima I. Org. Lett 2002;4:4575-4578. [PubMed: 12489933]

24. Cornille F, Fobian YM, Slomczynska U, Beusen DD, Marshall GR, Moeller KD. Tetrahedron Lett 1994;35:6989-6992.

25. Cornille F, Slomczynska U, Smythe ML, Beusen DD, Moeller KD, Marshall GR. J. Am. Chem. Soc 1995;117:909-917.

26. Slomczynska U, Chalmers DK, Cornille F, Smythe ML, Beusen DD, Moeller KD, Marshall GR. J. Org. Chem 1996;61:1198-1204.

27. Ojima I, Korda A, Shay WR. J. Org. Chem 1991;56:2024-2030.

28. Ojima I, Tzamarioudaki M, Eguchi M. J. Org. Chem 1995;60:7078-7079.

29. Ojima I, Vidal ES. J. Org. Chem 1998;63:7999-8003.

30. Ojima I, Iula DM, Tzamarioudaki M. Tetrahedron Lett 1998;39:4599-4602.

31. Ojima I. Pure Appl. Chem 2002;74:159-166.

32. Ojima, I.; Bonafoux, D.; Lee, S-Y. Encyclopedia of Catalysis. Horvath, IT., editor. 2. John Wiley \& Sons, Inc; Hoboken, New Jersey: 2003. p. 706-766.

33. Campi EM, Jackson WR, McCubbin QJ, Trnacek AE. Aust. J. Chem 1994;47:1061-1071.

34. Billig, E.; Abatjoglou, AG.; Bryant, D. 1988. Union Carbide: U.S.

35. Otsuka M, Kittaka A, Iimori T, Yamashita H, Kobayashi Susumu, Ohno M. Chem. Pharm. Bull 1985;33:509. [PubMed: 2410151]

36. McKillop A, Taylor RJK, Watson RJ, Lewis N. Synthesis 1994;1:31-33.

37. Deslongchamps, P. Stereoelectronic Effects in Organic Chemistry. Pergamon; New York: 1983. Chapter 6

38. Johnson F. Chem. Rev 1968;68:375-413.

39. Booth H, Everett JR. J. Chem. Soc., Chem. Commun 1976;8:278-279.

40. Booth HE, Jeremy R. J. Chem. Soc., Perkin Trans 1980;2(2):255-259.

41. Carroll, FA. Thomson Publishing Inc.; 1998. p. 138

42. Baldwin reported the strong directing effect of the Boc- $(S)$-serine residue on the selective formation of the $6 S$ bridgehead configuration in his tandem ozonolysis-cyclization of Boc- $(S)$-Ser- $(S / R)$ (homoallyl)Gly-OBn substrates, which gave the corresponding (6S)-1-aza-5-oxobicyclo[4.3.0] product in $72-77 \%$ yield with high diastereoselectivity $(6 S: 6 R=>7: 1)$ regardless of the absolute configuration of the homoallylglycine residue (see Ref. 22). Marshall also reported a similar directing effect of Boc- $(S)$-homoserine residue in his electrochemical (i.e., anodic electrolysis) cyclization of Boc- $(S)$-homo-Ser-(S/R)-Pro-OMe, which gave (7S)-1-aza-6-oxabicyclo[5.3.0] product exclusively, regardless of the absolute configuration of the proline residue although the chemical yields were only moderate $(48-52 \%)$ (see Ref. 26)

J Org Chem. Author manuscript; available in PMC 2008 September 1. 
(1)

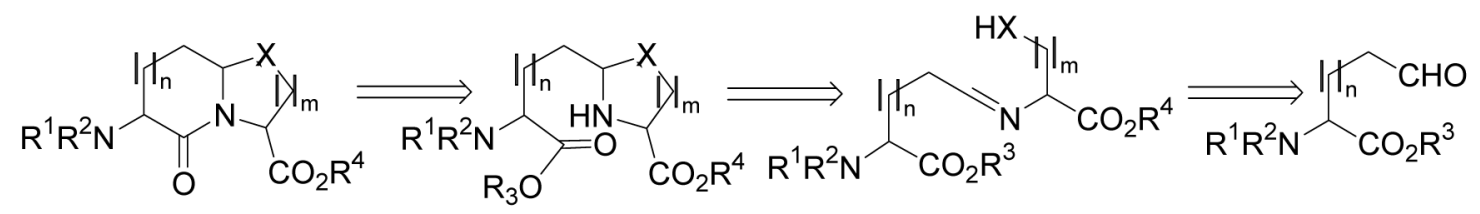

(2)

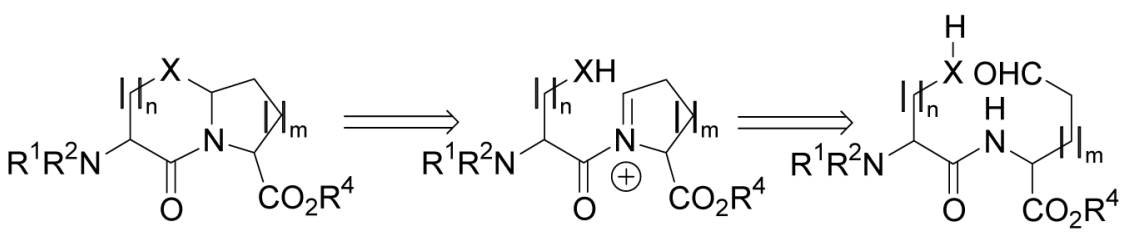

(3)

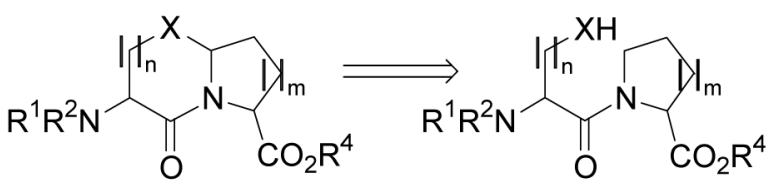

Scheme 1.

Representative routes to azabicyclo[x.y.0]alkane amino acids 


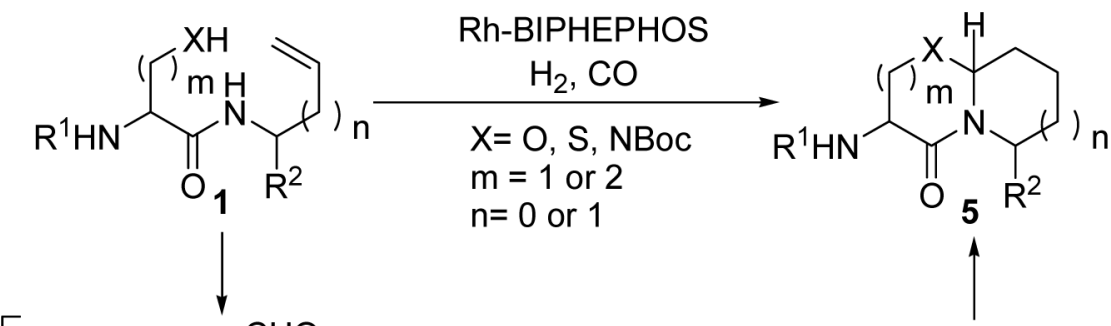

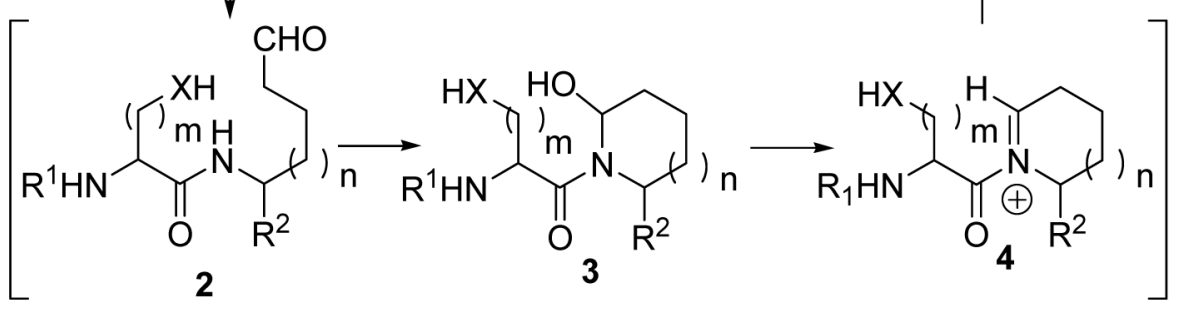

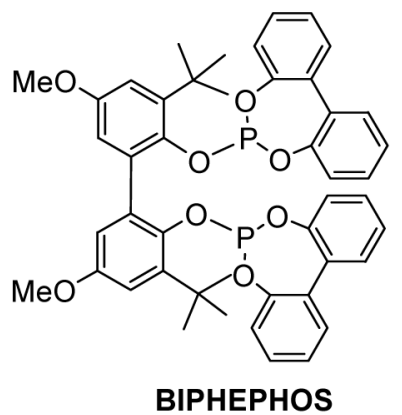

Scheme 2.

One-step synthesis of 1-azabicyclo[x.y.0]alkane amino acids through Rh-catalyzed cyclohydrocarbonylation (CHC) 
<smiles>C=CC[C@H](NC(=O)[C@H](CO)NC(=O)OCc1ccccc1)C(=O)OCc1ccccc1</smiles>

$(S, S)-\mathbf{2 a}, 94 \%$<smiles>C=CC[C@H](NC(=O)[C@@H](CO)NC(=O)OCc1ccccc1)C(=O)N[C@H]1CO[C@@H]2CCC[C@@H](C(=O)OCc3ccccc3)N2C1=O</smiles>

Reagents and Conditions: $\mathrm{Rh}(\mathrm{acac})(\mathrm{CO})_{2}$ (2 $\left.\mathrm{mol} \%\right)$, BIPHEPHOS (4 mol\%), $\mathrm{H}_{2}$ (2 atm), $\mathrm{CO}(2 \mathrm{~atm}), 65^{\circ} \mathrm{C}$, $20 \mathrm{~h}$; (i) toluene; (ii) toluene, PTSA (10 mol\%); (iii) toluene, DMAP (10 mol\%); (iv) THF.

Scheme 3. CHC of $(S, S)$-1a and $(S, R)-1 \mathrm{a}$

Reagents and Conditions: $\mathrm{Rh}(\mathrm{acac})(\mathrm{CO})_{2}$ (2 mol\%), BIPHEPHOS (4 mol\%), $\mathrm{H}_{2}$ (2 atm), CO (2 atm), $65^{\circ} \mathrm{C}, 20 \mathrm{~h}$; (i) toluene; (ii) toluene, PTSA (10 mol\%); (iii) toluene, DMAP (10 mol $\%$ ); (iv) THF. 


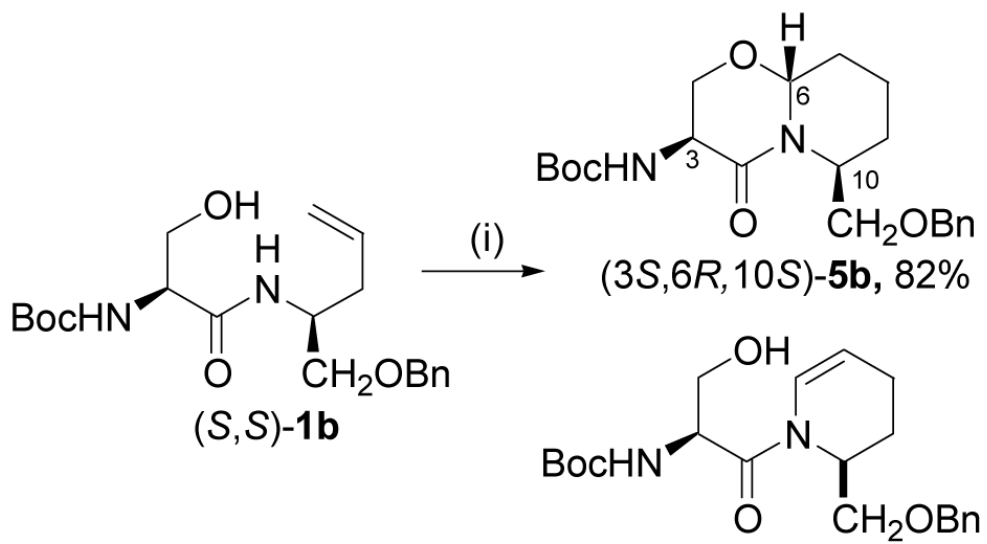
$(S, S)-6 b, 6 \%$

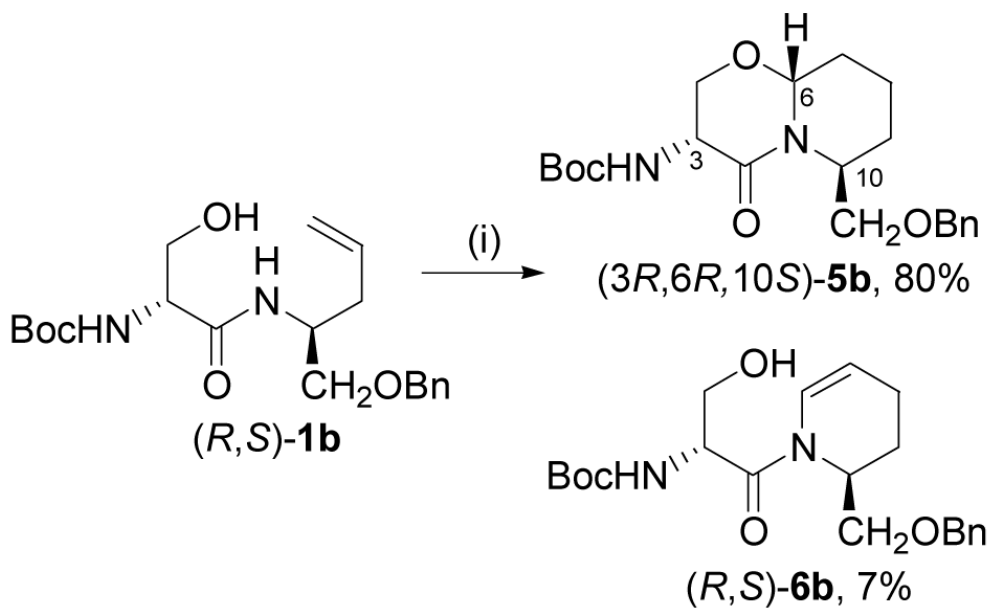

(i) $\mathrm{Rh}(\mathrm{acac})(\mathrm{CO})_{2}(2 \mathrm{~mol} \%)$, BIPHEPHOS (4 mol\%), $\mathrm{H}_{2}$ (2 atm), $\mathrm{CO}$ (2 atm), (PTSA (10 mol\%), toluene, 65 ${ }^{\circ} \mathrm{C}, 20 \mathrm{~h}$.

Scheme 4. CHC of $(S, S)-1 \mathrm{~b}$ and $(R, S)-1 \mathrm{~b}$

(i) $\mathrm{Rh}(\mathrm{acac})(\mathrm{CO})_{2}(2 \mathrm{~mol} \%)$, BIPHEPHOS (4 mol\%), $\mathrm{H}_{2}$ (2 atm), $\mathrm{CO}$ (2 atm), (PTSA (10 mol $\%)$, toluene, $65^{\circ} \mathrm{C}, 20 \mathrm{~h}$. 


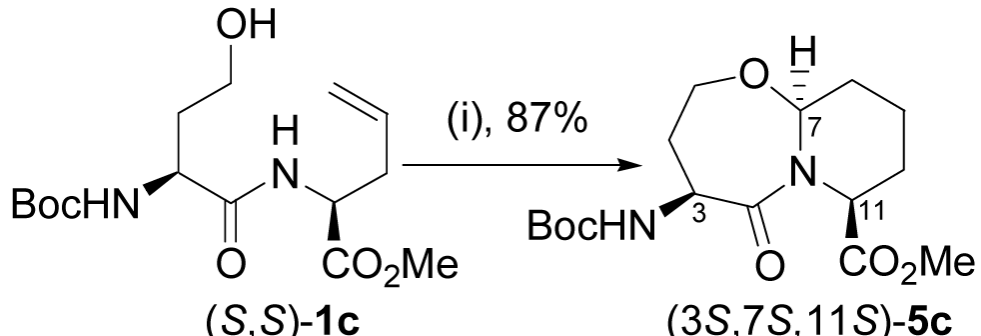

(i) $\mathrm{Rh}(\mathrm{acac})(\mathrm{CO})_{2}(2 \mathrm{~mol} \%)$, BIPHEPHOS (4 mol\%), $\mathrm{H}_{2}$ (2 atm), CO (2 atm), (PTSA (10 mol\%), toluene, $65^{\circ} \mathrm{C}$, $20 \mathrm{~h}$.

Scheme 5. CHC of 1c

(i) $\mathrm{Rh}(\mathrm{acac})(\mathrm{CO})_{2}(2 \mathrm{~mol} \%)$, BIPHEPHOS (4 mol\%), $\mathrm{H}_{2}$ (2 atm), $\mathrm{CO}$ (2 atm), (PTSA (10 mol $\%)$, toluene, $65^{\circ} \mathrm{C}, 20 \mathrm{~h}$. 


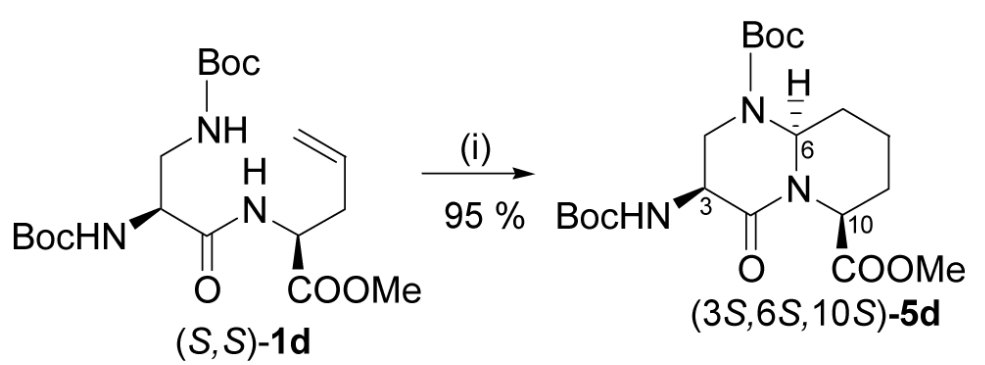

(i) $\mathrm{Rh}(\mathrm{acac})(\mathrm{CO})_{2}(2 \mathrm{~mol} \%)$, BIPHEPHOS (4 mol\%), $\mathrm{H}_{2}(2$ atm), CO (2 atm), (PTSA (10 mol\%), toluene, $65^{\circ} \mathrm{C}, 20 \mathrm{~h}$.

Scheme 6. CHC of $1 \mathrm{~d}$

(i) $\mathrm{Rh}(\mathrm{acac})(\mathrm{CO})_{2}(2 \mathrm{~mol} \%)$, BIPHEPHOS (4 mol\%), $\mathrm{H}_{2}$ (2 atm), $\mathrm{CO}$ (2 atm), (PTSA (10 mol $\%)$, toluene, $65^{\circ} \mathrm{C}, 20 \mathrm{~h}$. 


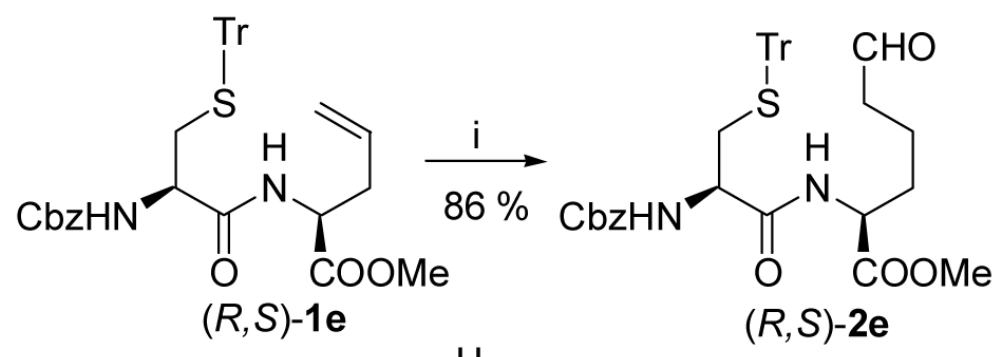<smiles>CO[C@H]1CCC[C@@H]2SC[C@H](NC(=O)OC(C)(C)C)C(=O)N12</smiles>

(i) $\mathrm{Rh}(\mathrm{acac})(\mathrm{CO})_{2}(2 \mathrm{~mol} \%)$, BIPHEPHOS (4 mol\%), $\mathrm{H}_{2}$ (2 atm), $\mathrm{CO}(2 \mathrm{~atm}), \mathrm{MeOH}, 65^{\circ} \mathrm{C}, 20 \mathrm{~h}$; (ii) TFA (cat.), $\mathrm{CH}_{2} \mathrm{Cl}_{2}, \mathrm{rt}, 30 \mathrm{~min}$.

\section{Scheme 7. CHC of 1e}

(i) $\mathrm{Rh}(\mathrm{acac})(\mathrm{CO})_{2}(2 \mathrm{~mol} \%)$, BIPHEPHOS (4 mol\%), $\mathrm{H}_{2}$ (2 atm), $\mathrm{CO}(2 \mathrm{~atm}), \mathrm{MeOH}, 65^{\circ} \mathrm{C}$, $20 \mathrm{~h}$; (ii) TFA (cat.), $\mathrm{CH}_{2} \mathrm{Cl}_{2}, \mathrm{rt}, 30 \mathrm{~min}$. 
<smiles>[3H]SCC[C@H](NC(=O)OCc1ccccc1)C(=O)N[C@@H](CC=C)C(=O)N[C@H](CCS[3H])C(=O)N[C@@H](CCCCO)C(C)=O</smiles>

$(S, S)-1 f$

$(S, S)-\mathbf{2 f}$

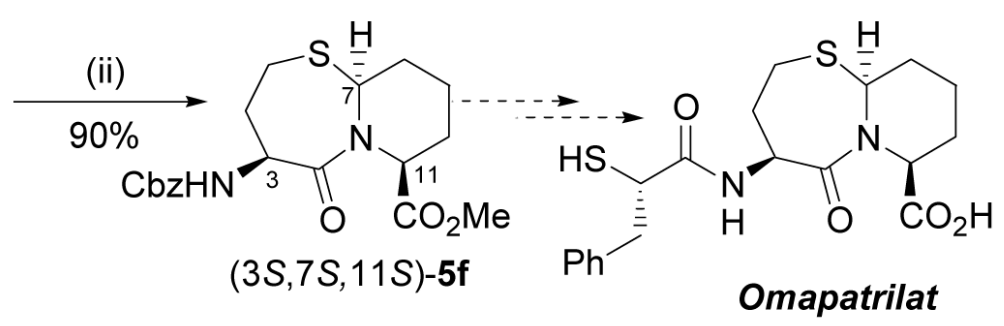

(i) $\mathrm{Rh}(\mathrm{acac})(\mathrm{CO})_{2}(2 \mathrm{~mol} \%)$, BIPHEPHOS (4 mol\%), $\mathrm{H}_{2}(2$ atm). $\mathrm{CO}(2 \mathrm{~atm}) \mathrm{MeOH} .65^{\circ}$ C. 20 h: (ii) $\mathrm{MeSO}_{2} \mathrm{H}(1 \%$ ).

Scheme 8. CHC of 1f

(i) $\mathrm{Rh}(\mathrm{acac})(\mathrm{CO})_{2}(2 \mathrm{~mol} \%), \mathrm{BIPHEPHOS}(4 \mathrm{~mol} \%), \mathrm{H}_{2}$ (2 atm), $\mathrm{CO}(2 \mathrm{~atm}), \mathrm{MeOH}, 65^{\circ} \mathrm{C}$, $20 \mathrm{~h}$; (ii) $\mathrm{MeSO}_{3} \mathrm{H}(1 \%)$, 


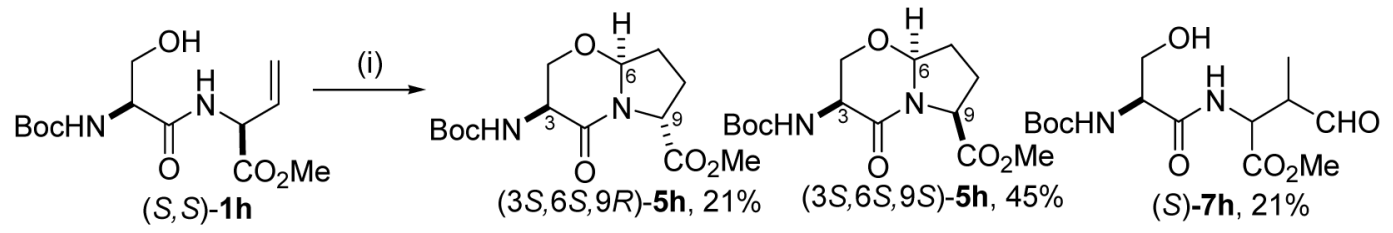

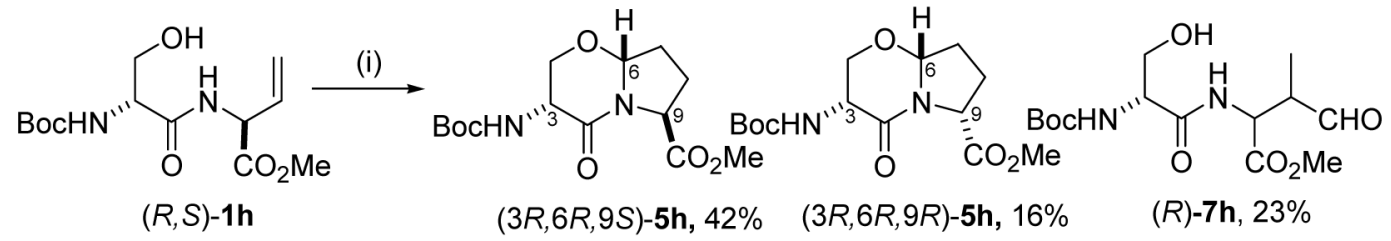

(i) $\mathrm{Rh}(\mathrm{acac})(\mathrm{CO})_{2}(2 \mathrm{~mol} \%)$, BIPHEPHOS (4 mol\%), $\mathrm{H}_{2}$ (2 atm), $\mathrm{CO}$ (2 atm), (PTSA (10 mol\%), toluene, $65^{\circ} \mathrm{C}, 20 \mathrm{~h}$.

Scheme 10. CHC to of $1 \mathrm{~h}$

(i) $\mathrm{Rh}(\mathrm{acac})(\mathrm{CO})_{2}(2 \mathrm{~mol} \%)$, BIPHEPHOS (4 mol\%), $\mathrm{H}_{2}$ (2 atm), $\mathrm{CO}$ (2 atm), (PTSA (10 mol $\%)$, toluene, $65^{\circ} \mathrm{C}, 20 \mathrm{~h}$. 
<smiles>C=C[C@H](C)NC(=O)[C@H](COc1ccccc1)NC(=O)OCc1ccccc1</smiles>
$(S, R)-1 \mathbf{i}$ $(3 S, 6 S, 9 R)-5 \mathbf{i}, 87 \%$

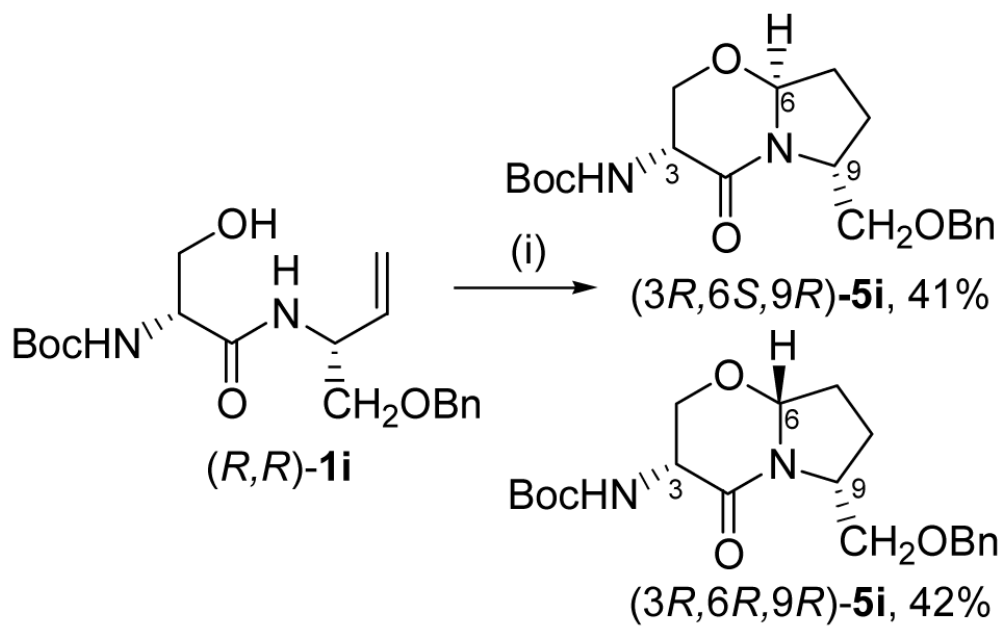

(i) $\mathrm{Rh}(\mathrm{acac})(\mathrm{CO})_{2}(2 \mathrm{~mol} \%)$, BIPHEPHOS (4 mol\%), $\mathrm{H}_{2}$ (2 atm), $\mathrm{CO}$ (2 atm), (PTSA (10 mol\%), toluene, 65 ${ }^{\circ} \mathrm{C}, 20 \mathrm{~h}$.

Scheme 11. CHC of $1 \mathrm{i}$

(i) $\mathrm{Rh}(\mathrm{acac})(\mathrm{CO})_{2}(2 \mathrm{~mol} \%)$, BIPHEPHOS (4 mol\%), $\mathrm{H}_{2}$ (2 atm), $\mathrm{CO}$ (2 atm), (PTSA (10 mol $\%)$, toluene, $65{ }^{\circ} \mathrm{C}, 20 \mathrm{~h}$. 
<smiles>C=C[C@H](C)NC(=O)[C@H](CO)NC(=O)O</smiles>

$(S, S)-\mathbf{1 j}$<smiles>C[C@H]1CC[C@]2(COC[C@H](NC(=O)OCc3ccccc3)C2=O)N1</smiles>

$(3 S, 6 S, 9 S)-5 \mathbf{j}, 94 \%$

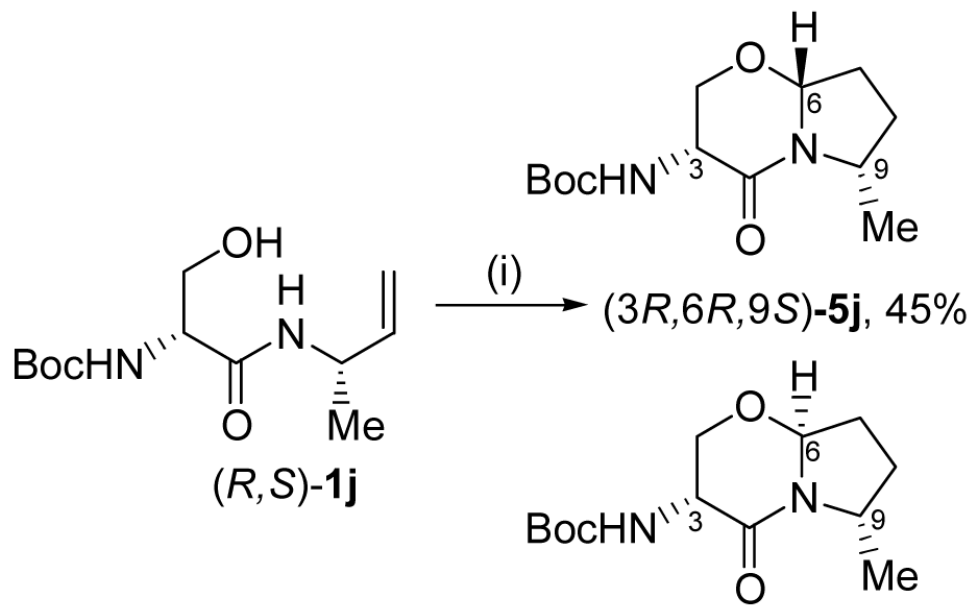

$(3 R, 6 S, 9 S)-5 \mathbf{j}, 34 \%$

(i) $\mathrm{Rh}(\mathrm{acac})(\mathrm{CO})_{2}(2 \mathrm{~mol} \%)$, BIPHEPHOS (4 mol\%), $\mathrm{H}_{2}$ (2 atm), $\mathrm{CO}$ (2 atm), (PTSA (10 mol\%), toluene, 65 ${ }^{\circ} \mathrm{C}, 20 \mathrm{~h}$.

Scheme 12. CHC of $1 j$

(i) $\mathrm{Rh}(\mathrm{acac})(\mathrm{CO})_{2}(2 \mathrm{~mol} \%)$, BIPHEPHOS (4 mol $\left.\%\right), \mathrm{H}_{2}$ (2 atm), $\mathrm{CO}$ (2 atm), (PTSA (10 mol $\%)$, toluene, $65^{\circ} \mathrm{C}, 20 \mathrm{~h}$. 


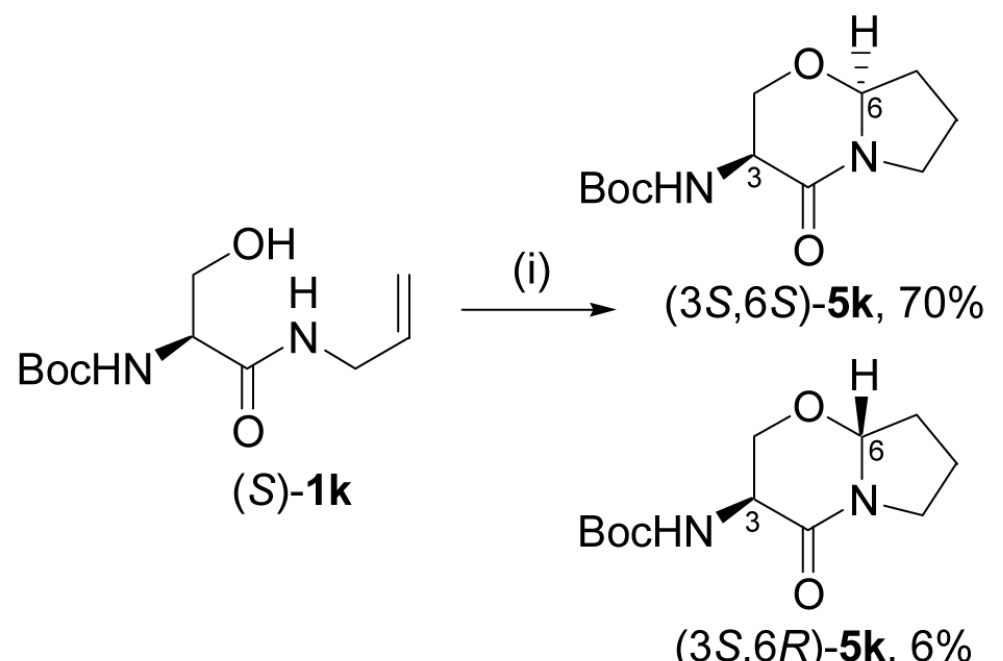

(i) $\mathrm{Rh}(\mathrm{acac})(\mathrm{CO})_{2}(2 \mathrm{~mol} \%)$, BIPHEPHOS (4 mol\%), $\mathrm{H}_{2}$ (2 atm), $\mathrm{CO}$ (2 atm), (PTSA (10 mol\%), toluene, 65 ${ }^{\circ} \mathrm{C}, 20 \mathrm{~h}$.

Scheme 13. CHC of $1 \mathrm{k}$

(i) $\mathrm{Rh}(\mathrm{acac})(\mathrm{CO})_{2}(2 \mathrm{~mol} \%)$, BIPHEPHOS (4 mol\%), $\mathrm{H}_{2}$ (2 atm), $\mathrm{CO}$ (2 atm), (PTSA (10 mol $\%)$, toluene, $65^{\circ} \mathrm{C}, 20 \mathrm{~h}$. 


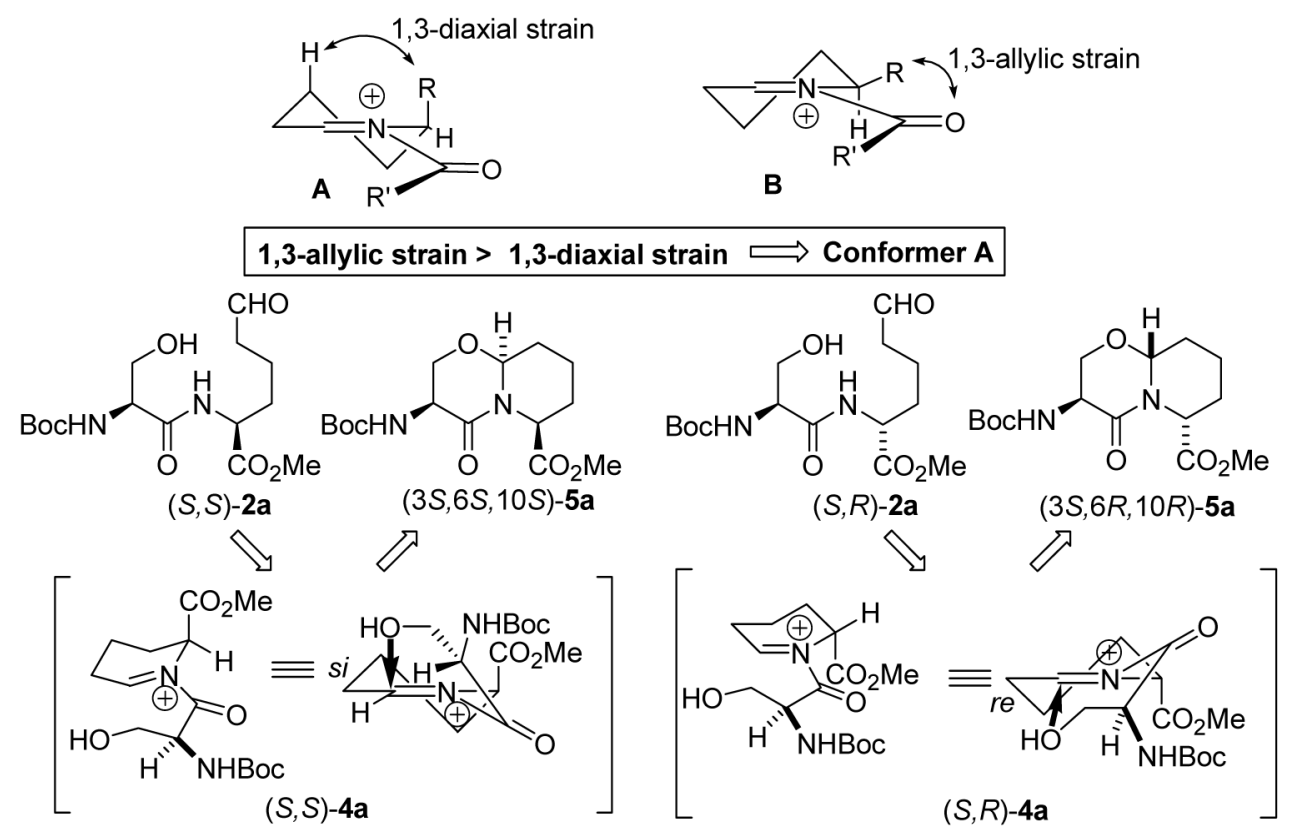

Scheme 14.

Mechanism of the extremely diastereoselective cyclization of $\mathbf{4 a}$ 

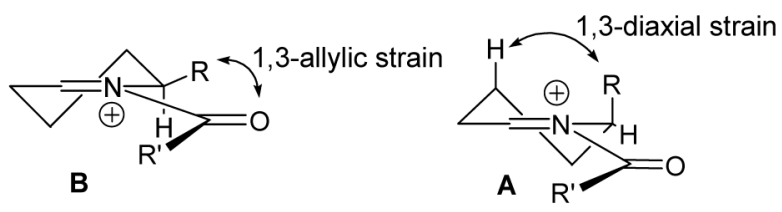

1,3-diaxial strain $>1,3$-allylic strain $\Longrightarrow$ Conformer $B$

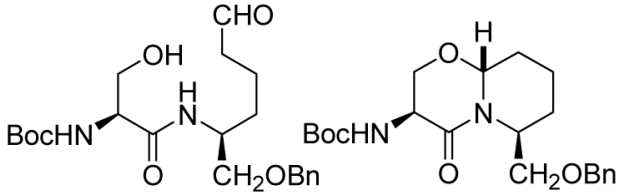

$(S, S)-\mathbf{2 b}$

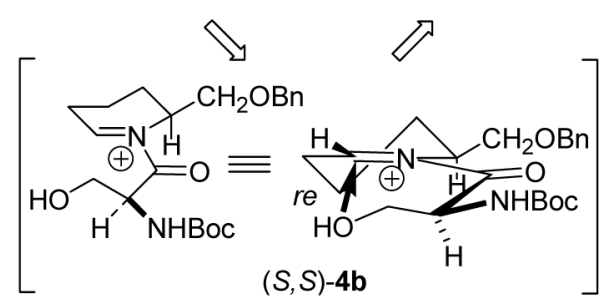

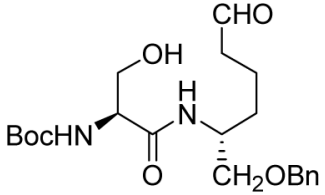

$(S, R)-\mathbf{2 b}$

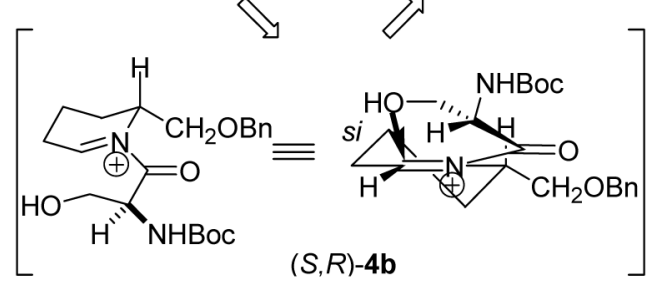

Scheme 15.

Mechanism of the extremely diastereoselective cyclization of $\mathbf{4 b}$ 
"exo-Methyl" Approach

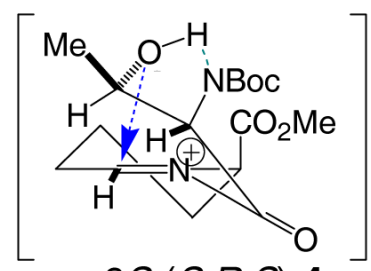

pro-6S- $(S, R, S)-\mathbf{4 g}$

$\rightarrow(S, R, S, S)-\mathbf{5 g}$, exclusive

\section{"endo-Methyl" Approach $\begin{aligned} & \text { "exo-Methyl" Approach } \\ & \text { with 1,3-Allylic Strain }\end{aligned}$}
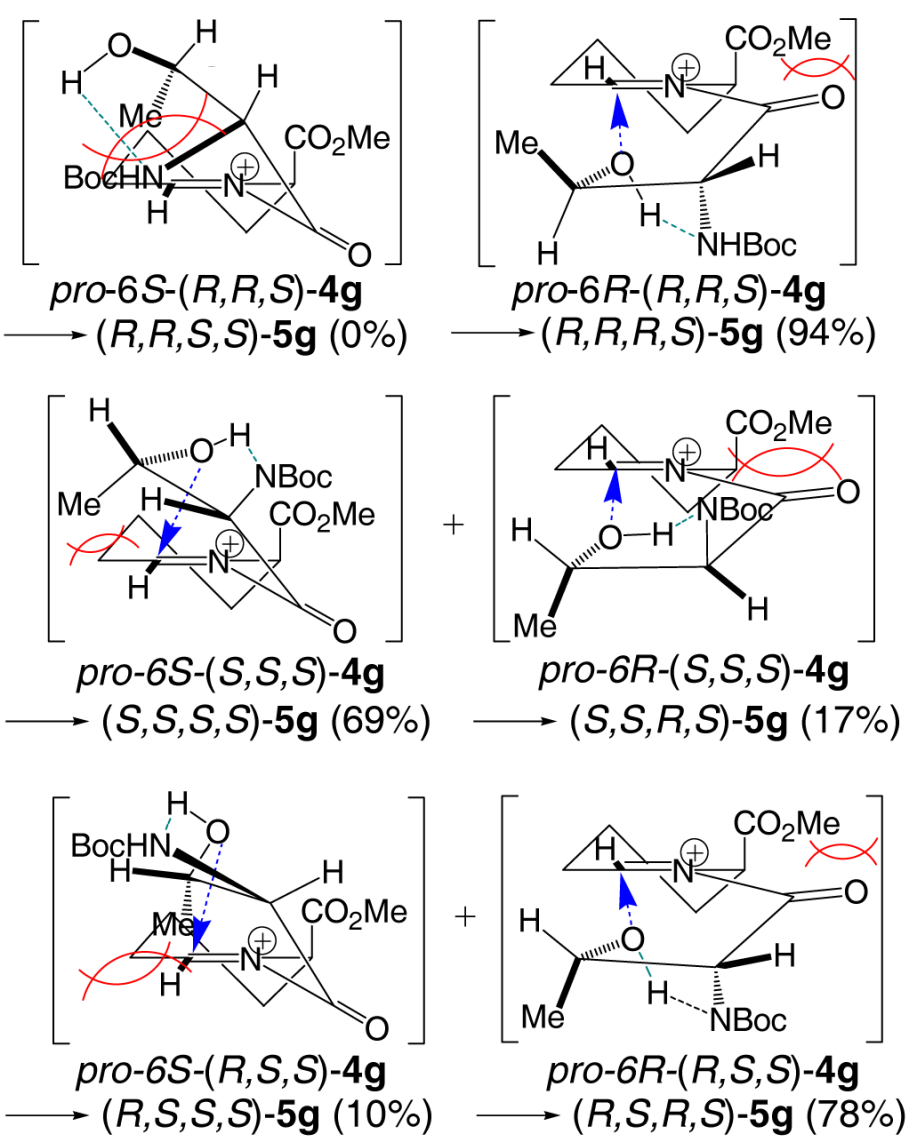

Figure 1.

Rationale for the diastereoselective cyclization of $\mathbf{4 g}$ 
<smiles>C=CC(NC(=O)[C@H](CO)NC(=O)OCc1ccccc1)C(C)=O</smiles>

$(S, S)-1 h \quad[R h]$<smiles>CCC(C)CO</smiles>

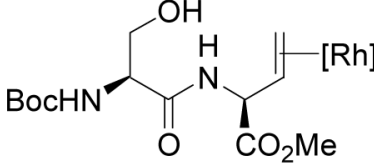

$(S, S)-1 \mathrm{~h}-\mathrm{Rh}$

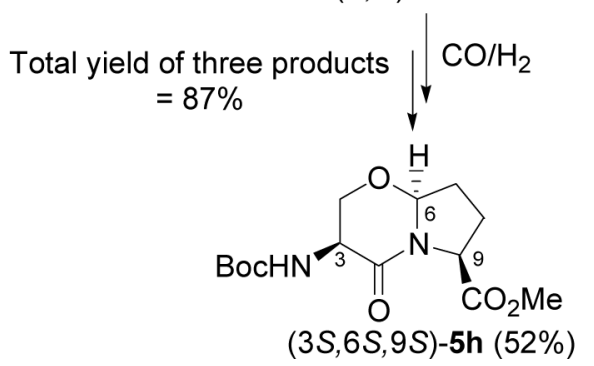

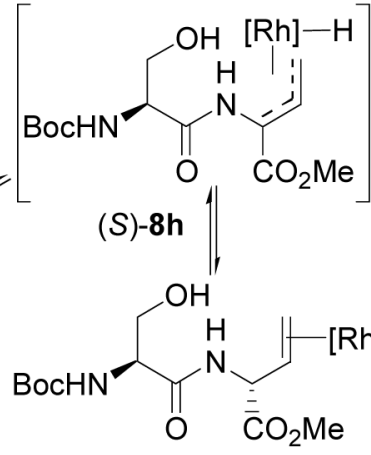

$(S, R)-1 h-R h$

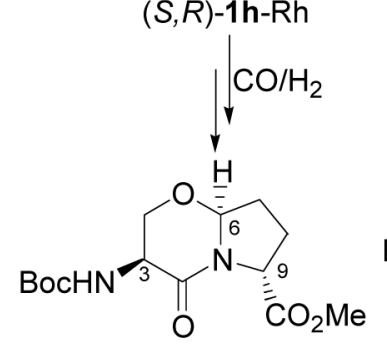

$(3 S, 6 S, 9 R)-5 h(24 \%)$

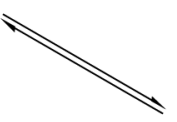

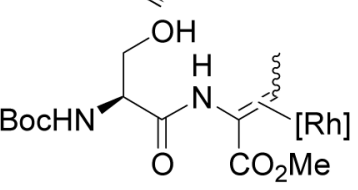

(S)-iso-1h-Rh

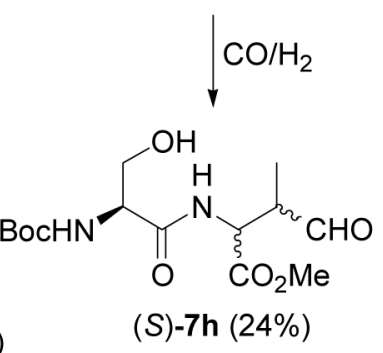

Scheme 16.

for the product distribution of the $\mathrm{CHC}$ of the vinylglycyl dipeptide $\mathbf{1 h}$ 


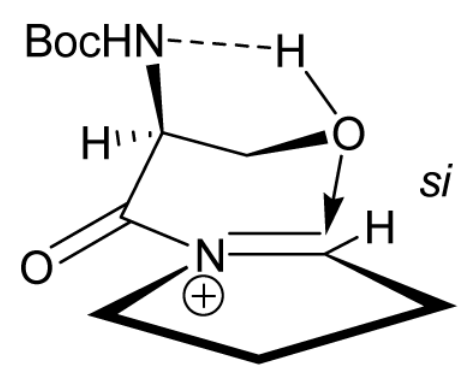

Pro-6S-4k si-face attack favorable

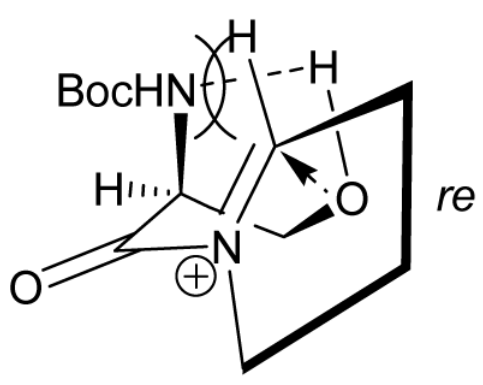

Pro-6R-4k re-face attack unfavorable

Figure 2. 